\title{
LÖKOSİT HÜCRELERİNİN PREPARAT GÖRÜNTÜSÜNDEN TESPITTI VE SINIFLANDIRILMASI
}

\author{
Ömer KASIM, Ahmet Emin KUZUCUOĞLU \\ Marmara Üniversitesi Bilgisayar-Kontrol Eğitimi Üsküdar İstanbul, Türkiye \\ Marmara Üniversitesi Teknoloji Fakültesi Elektrik-Elektronik Mühendisliği 34722, Kadıköy İstanbul, Türkiye \\ omerkasim@marun.edu.tr, kuzucuoglu@marmara.edu.tr
}

(Geliş/Received: 25.03.2014; Kabul/Accepted: 09.09.2014)

\begin{abstract}
ÖZET
Kan yapısının analiziyle hastalıkların teşhisinin konulması işlemi, mikroskop yardımıyla morfolojik incelemeye dayanır. Hematoloji uzmanları, preparatta bulunan lökosit hücrelerinin yapısını ve sayısını inceleyerek morfolojik incelemeyi gerçekleştirirler. Bu işlemler yoğun bir tempoda, boyama ve 1ş̧klandırma için ayrı bir çaba sarf etmeksizin yapılmaktadır. Böyle bir durumda hem gözden kaçabilecek bilgiler hem de uzmanın harcadığı zaman hayati öneme sahiptir. Bu sıkıntıları telafi etmek amacıyla geliştirilen algoritmayla, çok kaliteli hazırlanmamış preparat görüntüsünde bile lökosit hücrelerinin analizi yapılmaktadır. Böylelikle uzmana daha temiz ve net görüntüler sunularak zaman kaybı ve gözden kaçırma ile oluşabilecek hatalar en aza indirgenebilir. Diğer taraftan ülkemizdeki uzman sayısının yetersiz olması sebebiyle uzmanın olmadığı sağlık kuruluşlarındaki geliştirilen bu programla yapılan incelemelerde, hastalık belirtisi gösteren lökosit hücreleri tespit edilerek gerekli yönlendirmeler yapılır. Bu işlemler bütününü sağlamak için görüntü, Otsu yöntemi ile dinamiklik katılan Parçalı Lineer Filtre ile zenginleştirilerek lökosit hücre alanları daha belirgin hale getirilmiştir. Sonrasında KOrtalamalarla desteklenen Markov Rastsal Alanları ve Beklenti Enbüyükleme yöntemini içeren uzamsal yapıya sahip hibrit yapıyla lökosit hücre alanları bölütlenmiştir. Böylece farklı boyama kalitesi ve 1şılandırmadan kaynaklanan sıkıntılar en aza indirgenmiştir. Bölütlemeyle elde edilen lökosit alanları üzerinden öznitelik çıkarımıyla hücreye ait 34 farklı bilgiyi içeren öznitelik vektörü oluşturulmuştur. Gini analiziyle bu vektörün eleman sayısı 11'e düşürülmüştür. Bu çalışmada geliştirilen Cnt ve Sc Faktörlerle yapılan Gini analizinde bu sayı azalarak 5'e düşmüş ve 5 farklı lökosit hücresi olasılıksal yapay sinir ağlarıyla daha hızlı sınıflandırılmıştır. Sinıflandırma başarısı, test amacıyla ayrılan veri setinde \%91,65 olarak ölçülmüştür. Sonuçlar, bu alanda çalışma yapan uzmanlara ve uzmanın olmadığı ortamlarda gerekli yönlendirmelerin yapılmasına olanak sağlayacak niteliktedir.
\end{abstract}

Anahtar Kelimeler: Lökosit hücreleri, otsu metodu, parçalı lineer filtre, k-ortalamalar metodu, markov rastsal alan, beklenti enbüyükleme metodu, öznitelik çıkarımı, olasılıksal yapay sinir ağları, sınıflandırma

\section{DETECTION AND CLASSIFICATION OF LEUKOCYTE CELLS FROM SMEAR IMAGE}

\begin{abstract}
Diagnosis of diseases which are related to disorders of the leukocyte's structure is based on morphological examination methods. At the end of this examination, leukocyte's numbers, disorders and types of them are determined by hematology specialists without an intense pace for staining and lighting effort. Therefore, this process causes the loss of the vital information and time. The algorithm which is proposed in this study can support the specialists to examine the not well stained smear easily. Thus, specialists and proposed algorithm can observe the cells' structure on a clear image and classify them into five categories without loss of information. In this manner, quick examination, loss of time, inadequate specialists and diagnosis problems can be solved by the proposed algorithm. At first step of our algorithm, the leukocyte's area is enriched with Otsu based dynamic Piecewise Linear Filtering Method. After that a hybrid spatial learning structure which is composed of K-Means, Markov Random Field and Maximization Expectation Method has been used to get Region of Interests. This hybrid method minimizes the quality of different staining and lighting problems. At analysis step, we obtained
\end{abstract}


34 different vector elements of each Region of Interests. The member of this vector is dropped to 11 by Gini Method. The Cnt Factor and Sc Factor which are proposed in this study decrease this number of feature set into 5. This also reduces the classification pace. Then, this vector is divided into 5 different classes with Probabilistic Neural Network. Classification performance of the allocated data set is measured as $91.66 \%$. The obtained results can support the specialist and the proposed algorithm can give useful information about the smear if there isn't any specialist.

Keywords: Leukocyte cells, otsu method, pice-wise linear filter, k-means method, markov random field, maximization expectation method, feature extraction, probabilistic neural networks, classification

\section{GIRİS (INTRODUCTION)}

Lökositler, savunma mekanizması olarak bizleri enfeksiyonlara karşı koruyan kan hücreleridir. Bu hücreler boyutları, şekilleri, renkleri ve sitoplazmaçekirdek oranlarına bakılarak 5 ana kategoriye ayrılır. Bunlar lenfosit, nötrofil, monosit, bazofil ve ezonofildir. Kanın yapısında, özellikle lenfosit ve nötrofil hücreleri diğer lökosit hücrelerine oranla daha fazla gözlenmektedir. Bunun nedeni nötrofil hücrelerinin mikroorganizmalara karşı savunmada önemli rol oynaması ve lenfosit hücrelerinin de bağışıklık görevlerinin yanında virüslere karşın etkin savunma sağlamasıdır. $\mathrm{Bu}$ hücrelerin her birinin sayısının belirli oranlarda artmış olması ilgili grubun enfeksiyon durumunun göstergesidir. Fakat lenfosit hücresinin sayısı artarken diğerlerinde bir artış olmaması lösemi hastalığının teşhisi için bir uyarı durumu taşımaktadır. Diğer taraftan lenfosit hücrelerinin sayısının azalması lökopeni teşhisinin belirtisidir. Aynı durum nötrofil hücreleri için de geçerlidir. Nötrofil hücrelerinin fazlalaşması bakteri kaynaklı bir hastalığın habercisidir. Bu tür durumlar uygulama alanında yapılan tahliller ve yayma işlemi ile belirlenmektedir. Günlük hayatta farklı hücre sayma ve tanıma yöntemleri mevcuttur [1]. Pratik uygulamalarda kullanılan bu yöntemler sonuca hizlı ulaşmayı kolaylaştırır. Fakat daha doğru ve kesin teşhis koymak adına kan yayması incelemesi yapılması literatürde kabul görmektedir [2]. Tipik bir kan yayması ile bu hücreler mikroskop yardımıyla gözlemlenir. Bu gözlem sonucunda iki önemli analiz işlemi yapılır. İlk adımda belli bir alanda yer alan lökosit hücrelerinin sayımı yapılırken diğer analiz adımında ise eritrosit, lökosit ve trombosit hücrelerinin yapıları incelenir [3]. Bu işlem adımında lökosit hücrelerinin yapılarının değişiminin gözlenmesi çeşitli hastalıkların teşhisinde önemli bir yer tutar. Özellikle lösemi teşhisi için lenfosit hücrelerinin yapısının incelenmesi hayati öneme sahiptir. Günümüzde bu işlemler, hematoloji uzmanlarının kendi tecrübeleriyle yapılmaktadır. Fakat bu analiz oldukça zaman alıcı bir işlemdir. Klasik yöntemler ile yapılan analiz çalışmalarında her 100 hücrenin sadece yerlerinin tespiti ve sayısının belirlenmesi için yaklaşı 15 dakika süre harcanmaktadır [4]. Her gün onlarca kişinin bu tetkiki yaptırdığı düşünüldüğünde uzmanlar zamanlarının büyük çoğunluğunu bu analiz işlemi için harcamaktadırlar. Uzmanların yaptıkları bu analiz işlemi sonucu farklı yorumlar yapılabildiğinden objektif bir sonuç ortaya konulması için gerektiğinde ikinci ya da üçüncü bir uzmanın yorumu gerekmektedir. Diğer taraftan hematoloji uzmanlarının bulunmadığı yerlerdeyse bu tip analizler yapılamamaktadır. $\mathrm{Bu}$ sebeplerden dolayı lökosit hücre sayısını belirleyen ve bu hücreleri sınıflandıran otomatik bir hücre analiz sistemi geliştirilmesi sektörde çözüm bulunması gerekli önemli bir problem olarak karşımıza çıkmaktadır.

$\mathrm{Bu}$ sistem öncelikle bilgisayar ortamına aktarılan görüntü içinde yer alan lökosit hücrelerini preparat görüntüsünden ayırmalıdır. Ayırma işleminin hatasız ve sabit işlemlerle gerçekleştirilmesi mümkün olamamaktadır. Bunun nedenlerinden önemli olanları; preparatların boyanması esnasında ortam sıcaklığı, nem ve boyama süresi gibi faktörler ile kullanılan mikroskobun merceğinin kalitesi, 1şık miktarı ve büyütme oranı farklılıkları olarak sayılabilir. Dolayısıyla analiz edilmek istenen görüntünün netliği ve hücrelerin renk kalitesi dinamik bir özelliğe sahiptir. Literatür incelendiğinde bu tür sorunları çözmek için bilgisayar destekli kan örneği incelenmesinde, eritrosit, lökosit ve trombositlerin bölütlenmesi için çeşitli algoritmalar kullanılmaktadır. $\mathrm{Bu}$ işlemi gerçekleştirmek için 4 ana kategori üzerine yoğunlaşılmıştır. Piksel tabanlı yöntemlere bakıldığında bölütleme işlemi, pikselin aldığı renk değerleri ve renk özelliklerine göre yapılmaktadır. Böyle bir yöntemde lökosit hücresinin preparat üzerinde tanınması için piksel yoğunluğuna bağlı bir eşik değeri seçilerek bölütlenmeye çalışılmıştır. Belirlenen eşik değerleri hücreyi ve hücre çekirdeğini ayırt etmek için kullanılmaktadır [5]. Literatürde watershed algoritması ile desteklenerek bu yöntemin başarı oranı artırılmaktadır [6]. Ayrıca çok seviyeli spektral analiz ile görüntülerin elde edilmesi, eşikleme yönteminin başarısını artırmaktadır [7]. Alan gelişimi yöntemi kullanılarak geliştirilen çalışmalarda, bir başlangıç noktası belirlenmiş, etrafındaki ilgili piksel değerleri de kendisine katılarak bölütleme işlemi gerçekleştirilmiştir. Sınıflandırma aşamasında ise Bayes sınıflandırma, KOrtalamalar ve kümeleme algoritmaları kullanılmıștır [8,9]. Çevre belirleme algoritmalarını temel alan çalışmalarda ise aktif kontur yöntemi ve level-set yaklaşımları kullanılmaktadır. $\mathrm{Bu}$ yöntemlerdeki amaç ise hücre çekirdeği ve sitoplazmanın çevreleri belirlenerek bölütleme işlemini gerçekleştirmektir. Bu 
noktada iki farklı çevre bilgisi vardır. Bir tanesi hücrenin çevresini oluşturan ayırt bilgisiyken diğeri ise hücre çekirdeğinin çevreleyen çevre çizgisidir [10,11]. Ayırt tabanlı bölütleme işlemlerinde, oluşturulan bir maske operatörü ile belirli açısal doğrultudaki yoğunluk farklılıkları arasındaki geçiş hızı hesaplanır. Bu hızdaki artışın doğrultusunu veren her noktadaki görüntü yoğunluğunun gradyanı bulunur. Bulunan bu sonuç o noktadaki görüntünün ne kadar hızlı ya da yavaş değiştiğini gösterir. Gradyan değerinin büyük olduğu bölgeler hızlı geçişlerin olduğu bölgeler olduğu için nesnelerin sınırlarını ifade eder. Sinırların bu şekilde birleştirilmesi ile kapalı bir alan içine alınan nesnelerin çevreleri belirlenir. Sınır belirlemede Laplacian of Gaussian, Canny ve Sobel matrisleri, sınır belirlemede kullanılan operatörlerdendir $[12,13]$. Bu yöntemlerin çevre bilgilerinin elde edilmesinde kullanılmasıyla hücrenin bütün olarak sınır bilgileri elde edilmektedir [14]. Diğer taraftan sitoplazma ve çekirdek ayırtlarının pekiştirilerek bölütleme işlemi yapılan bu çalışmalarda doku analizinden elde edilen öznitelik bilgileri kullanılarak lökosit hücreleri analiz edilmiştir [15]. Elde edilen öznitelik bilgilerinin yapay sinir ağları ile incelenerek bu hücreler sınıflandırılmaya çalışılmıştır [16]. Tam otomatik yapılan sınıflandırma işleminde sadece lenfosit hücreleri sınıflandırılmakta fakat diğer lökosit hücre türleri sınıflandırmaya dahil edilmemektedir [17]. Gradyan tabanlı bir bölütleme algoritmasıyla farklı boyama koşulları için gerçekleştirilen tam otomatik tasarıma sahip bir çalışmada ise lökosit hücreleri ve çevre bilgileri elde edilmekte fakat sınıflandırma işlemi yapılmamaktadır [18].

$\mathrm{Bu}$ çalışmada geliştirilen algoritma, Giemsa Boyası ile boyanmış preparatların, mikroskop altında incelenmesini esas almaktadır. Geliştirilen yöntem 1şıklandırma koşullarından bağımsız olarak ve çok özen gösterilmeden boyama yapılsa bile görüntünün MRA ile modellenerek analizini yapabilme özelliğine sahip tam otomatik olarak tasarlanmış bir görüntü işleme uygulamasını içermektedir. Çalışmada, Otsu metoduyla dinamiklik kazandırılan Parçalı Lineer Filtre (PLF) görüntü zenginleştirme algoritması ile görüntü üzerindeki boyama, 1şıklandırma ve mercek kalitesinden kaynaklanan sikıntılar en aza indirgenmiştir. Böylelikle uzmanlar ve geliştirilen sınıflandırma algoritması, dağınık ve kalitesiz bir alanı incelemek yerine daha temiz ve düzenli bir görüntü üzerinden yorum yapabilmektedirler. $\mathrm{Bu}$ durum çalışma ortamında verimi artıran önemli faktörlerden birisidir. Tam otomatik bir sistem tasarımı düşünüldüğünde uzamsal öğrenme çalışmaya diğer yöntemlerden farklı bir özellik katmaktadır. Komşu piksellere bakarak bölütleme işlemi yapılmasına olanak sağlayan uzamsal öğrenme yöntemi ile diğer yöntemlerde sunulan yarı otomatik ya da 1şığa karşı duyarlılık sıkıntıları en aza indirgenmektedir. $\mathrm{Bu}$ durum K-Ortalamalar, Markov
Rastsal Alanlar (MRA) ve Beklenti En-büyükleme Metodu (BEM) algoritmalarının birleşimiyle oluşturulan hibrit yapı ile sağlanmaktadır. Sınıflandırma adımına hazırlık için öznitelik analizi yapılmıştır. Gini Analizi Yöntemi ile yapılan bu deneyde, 11 farklı öznitelik ile test verilerinin sınıflandırılabileceği sonucu ortaya çıkmıştır. Bu çalışmada geliştirilen Cnt Faktör ve Sc Faktör özniteliklerinin veri setine eklenmesiyle bu sayı 5 öznitelik bilgisine indirilmiştir. Böylece sınıflandırma adımında kullanılan olasılıksal yapay sinir ağları (OYSA) modelinin çalışma performansı arttırılmıştır. Böylelikle geliştirilen bu sistem uzmanların ve otomatik sistemin preparatları incelemede harcadıkları zamanı büyük ölçüde azaltmıştır. Diğer taraftan geliştirilen yöntem, her durumda aynı hücre bilgisini uzmana sunacağından farklı görüş ve düşünce sonucunda teşhiste yaşanacak sıkıntıların da önüne geçilmesine katkı sağlamaktadır. Çalışmanın bir diğer önemli katkısı ise hematoloji uzmanının olmadığ 1 birimlerde lösemi teşhisinin erken konulabilmesi adına ön incelemenin yapılmasına ve gerekli uzmanlara yönlendirilmesine imkan sağlayabilmesidir.

\section{MATERYAL VE METOT (MATERIAL AND METHOD)}

\subsection{Sistemin Genel Akışı (Overwiev of The Automated System)}

Oluşturulan sistemin genel akış şeması Şekil 1'de gösterilmiştir. Algoritma, görüntünün bilgisayar ortamına alınmasıyla başlar. İlk adım olan ön işleme adımında, mikroskoptan bilgisayar ortamına aktarılan görüntülerin insan görmesine daha yakın olan ve aydınlatma ile doygunluk olaylarını farklı olarak elde etmemizi sağlayan Açı, Doygunluk, Yoğunluk (HSI) renk uzayına geçilir. Bu uzayda oluşan doygunluk matrisi (S) ile gri seviye görüntüsü oluşturulur. $\mathrm{Bu}$ görüntü matrisi, Otsu yöntemiyle dinamiklik kazandırılan PLF yapısından geçirilir. Böylelikle tekrar RGB olarak organize edilen görüntüde, lökosit hücre alanları daha belirgin olarak elde edilir. Tekrar derlenen görüntünün International Telecominacation Union (ITU) dönüşümüyle 8 bitlik gri seviye görüntüsü elde edilerek bölütleme adımına geçilir. Bu adımda ilk olarak görüntünün MRA yapısı, 8 komşuluklu olarak elde edilir. Elde edilen MRA matrisi üzerine K-Ortalamalar algoritması uygulanır. $\mathrm{Bu}$ işlem sonucu 3 küme merkezi elde edilir. $\mathrm{Bu}$ merkez bilgileriyle çok seviyeli BEM yapısının sınır değerleri belirlenir. Böylelikle bölütleme işlemi, BEM algoritmasının her bir küme sınır değerleriyle MRA matrisi üzerinde çalıştırılmasıyla sonlandırılır. $\mathrm{Bu}$ adım sonrasında her bir lökosit hücresi, 3 seviyeli olarak bölütlenmiş haliyle lökosit hücre alanları (ROI) olarak organize edilir. Sınıflandırma adımı için öncelikle oluşturulan bu ROI görüntülerine ait öznitelik vektörü elde edilir. Şekilsel ve istatistiksel analiz ile elde edilen vektör bilgileri ve Cnt Faktör ile 


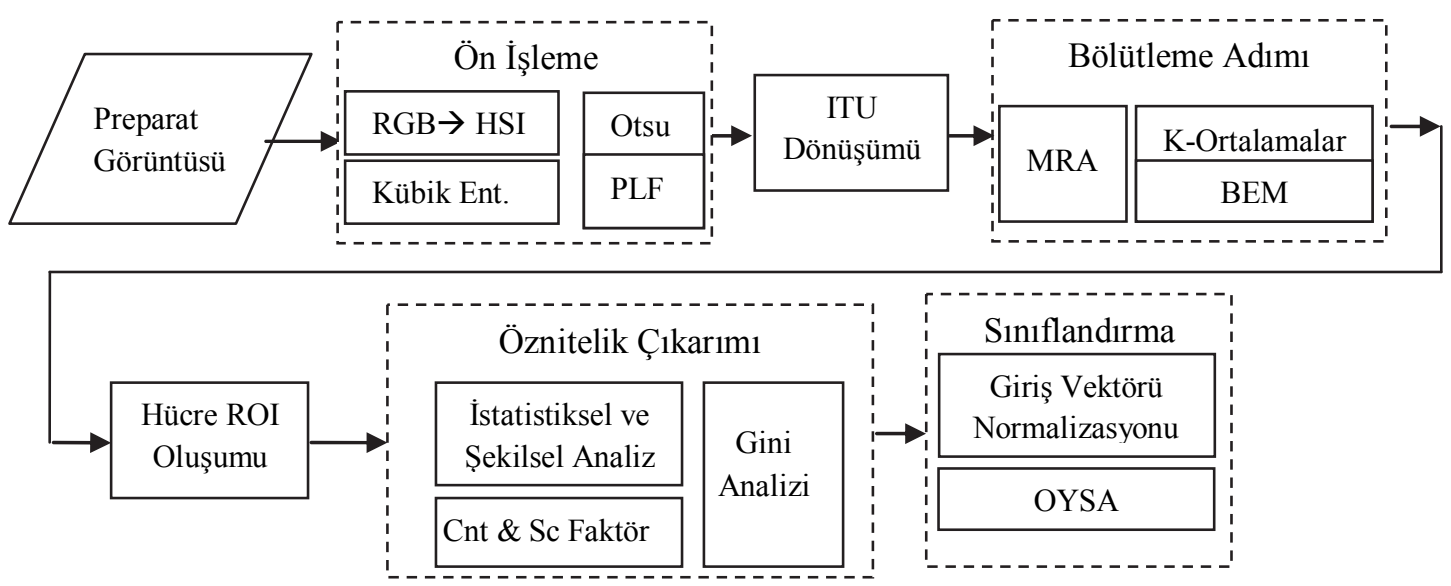

Şekil 1: Sistemin Genel Akış Diyagramı (Block Diagram of the System)

Sc Faktör, Gini analizinden geçirilir. Gini analizi sonucu çalışmada geliştirilen Cnt ve Sc fakötleriyle beraber 5 lökosit türü için ayırt edici özelliği yüksek olan 5 öznitelik bilgisi elde edilir. Bu 5 öznitelik bilgisinin 0-20 arasinda normalizasyonu ile veri tabanında bulunan hücreler OYSA ile 5 kategoriye siniflandirilır.

\subsection{Görüntünün Alınması (Image Acqusition)}

Görüntülerin alınmasında 10x, 40x ve 100x büyütme oranına sahip standart bir mikroskop kullanılmaktadır. Mikroskobun oküler kısmina monte edilen DCM serisi olan D510 türü 5 megapiksel çözünürlüğe sahip kamera ve 1 ş1k geçirmez aparatı ile preparat görüntüleri eş zamanlı olarak USB bağlantısı yoluyla bilgisayar ortamına aktarılmaktadır. $\mathrm{Bu}$ işlemler bütünü, eş zamanlı olarak üçüncü parti yazılım olan scopephoto ya da geliştrilen yazılımın ara yüzü kullanılarak sağlanmaktadır. Böylelikle eğitimaraştırma hastanelerinin hematoloji bölümlerinden temin edilen ve giemsa boyası ile boyanmış preparatlar, JPEG biçimiyle ve 2592x1944 çözünürlüğe sahip olarak veritabanına kayıt edilmiştir.

$\mathrm{Bu}$ görüntülerin her biri 350 Kilo Bayt yer kaplamaktadır. Oluşturulan bu veritabanı içerisinde 16 adet nötrofil sayısı artmış enfeksiyon durumu, 26 adet Akut Lenfoblastik Lösemi (ALL) vakası ve 52 adet de Akut Myeloblastik Lösemi (AML) vakası teşhisi konmuş preparat bulunmaktadır.

Hastalık teşhisi konan bu preparatların yanında uzmanlar tarafindan sağlıklı olarak belirlenmiş 26 preparat da bu bölüme eklenmiştir. Böylece toplamda 120 preparattan, 1şıklandırma koşulları değiştirilerek 188 görüntü eş zamanlı olarak alınarak kayıt edilmiştir. $\mathrm{Bu}$ durum algoritmanın gerçek hayat görüntüleri üzerindeki etkinliğini test etmek açısından önem arz etmektedir. Diğer taraftan çalışmanın amacına uyması bakımından ve gözlemlenebilecek her bir farklı lökosit hücresini barındırması bakımından Utah Üniversitesi veri seti ile veritabanı zenginleştirilmiştir [19]. Böylelikle uzmanların preparatları incelerken gözlemleyebilecekleri tüm ihtimaller, Utah Üniversitesi'nden alınan 40 preparat görüntüsü ile sağlanmaktadır.

\subsection{Görüntü Önişleme (Image Pre-processing)}

Günlük hayat uygulamalarından alınan preparat görüntüleri incelendiğinde, boyama işleminin hızlı ve özensiz yapıldığı tespit edilmiştir. Bu sıkıntıyı en aza indirmek ve lökosit hücre alanlarını daha belirgin hale getirmek için ön işleme adımında HSI uzayına geçilerek dinamik bir PLF tasarımı yapılmıştır.

\subsubsection{RGB-HSI Dönüşümü (RGB-HSI Transformation)}

Gri seviye görüntü elde edilmesi amacıyla, HSI renk uzayının doygunluk matrisi (S) kullanılmıştır. Bu matris eşitlik 1 kullanılarak RGB renk uzayından elde edilmiştir.

$\mathrm{S}=1-\frac{3}{(\mathrm{R}+\mathrm{G}+\mathrm{B})}[\min (\mathrm{R}, \mathrm{G}, \mathrm{B})]$

Eşitlik 1 sonucu oluşan $S$ matrisi 0-255 arasına uyarlandığında gri seviye görüntü oluşur. Oluşturulan bu görüntü üzerindeki parlak olan alanlar lökosit hücresinin çekirdek bilgilerini barındırmaktadır. Orta seviye parlaklık bilgileri lökosit hücrelerinin çekirdek bilgisi ile eritrosit hücrelerinin bulunduğu alanları ifade etmektedir. Daha zayıf doygunluk bölgeleri ise arka plan olarak gözlemlenmiştir.

\subsubsection{Kübik Enterpolasyon (Cubic Interpolation)}

Algoritmanın hızını artırmak ve veri kaybını minimize etmek için kübik enterpolasyon yöntemiyle görüntü matrisi boyutları küçültülmüştür. Kübik enterpolasyon yöntemi $I(i, j)$ orijinal görüntüsündeki ilgili pikselinin çevresindeki $4 \times 4$ komşuluğundaki 16 pikselin $\mathrm{I}(\mathrm{i}, \mathrm{j})$ pikseline ağırlıklı uzaklıkları 
hesaplanarak yeni piksel değerinin bulunmasıdır. Bu değerler eşitlik 2 ile hesaplanır.

$$
I^{1}(i, j)=\sum_{m, n=1}^{2} I(i+m, j+n) F(m-d x) F(d y-n)
$$

Eşitlik 2'de $m$ ve $n$ ifadeleri ilgili pikselin $4 \times 4$ komşuluğundaki 16 pikselin değerleridir. F ifadesi kübik ağırlık fonksiyonu olarak ifade edilir ve eşitlik 3 ile hesaplanır. $\mathrm{Bu}$ işlem sonucu küçültülen görüntüdeki yeni I ${ }^{1}$ değeri hesaplanmaktadır.

$$
\begin{aligned}
& F(x)=\frac{1}{6}\left[P(x+2)^{3}-4 \cdot P(x+1)^{3}+6 \cdot P(x)^{3}-\right. \\
& \text { 4. } \left.P(x-1)^{3}\right]
\end{aligned}
$$

\subsubsection{Otsu Yöntemi (Otsu Method)}

Boyutları indirgenen S matrisi görüntüsünün iki farklı alan olarak ayrılması işlemi, Otsu yöntemiyle sağlanır. $\mathrm{Bu}$ işlemdeki amaç, PLF yapısındaki sınır noktalarının ve eğim miktarının elde edilmesidir. Bunu sağlamak için $\mathrm{t}$ eşik değerinin belirlenmesi gereklidir. Görüntü üzerindeki alanların ayrılabilirliği kullanılarak belirlenen sinıflardan birini maksimum yapacak $t$ eşik değerinin en büyük olduğu değer eşitlik 4 ile hesaplanır [21].

$\sigma^{2}(t)=\frac{\left(\mu_{T} w(t)-\mu(t)\right)^{2}}{w(t)(1-w(t))}$

Eşitlik 4'te $\sigma^{2}$ ifadesi varyansı ifade ederken $\mu_{\mathrm{T}}, \mathrm{S}$ görüntü matrisinin ortalama değerini ifade etmektedir. $\mathrm{w}(\mathrm{t})$ histogramin sıfirıncı dereceden momentini, $\mu(\mathrm{t})$ ise histogramın birinci dereceden momentini ifade etmektedir. Seçim kriteri ise eşitlik 5 ile ifade edilir. Böylelikle varyansı en büyük yapan en uygun $t^{1}$ eşik değeri eşitlik 5 ile hesaplanır [21].

$\sigma^{2}\left(t^{1}\right)=\max \left(\sigma^{2}(t)\right)$

\subsubsection{Parçalı Lineer Filtre (Piece-wise Linear Filtering)}

Otsu metoduyla histogram üzerinde belirlenen sınır değerleri (A ve B noktaları) 3 parçalı PLF yapısının $\mathrm{x}_{1}$ ve $x_{2}$ noktalarına atanır. Böylelikle görüntünün zenginleştirilmesinde kullanılacak her bir parça elde edilir. Belirlenen parçaların eğimleri dikkate alınarak görüntü baştan oluşturulur. 3 parçadan oluşan PLF yapısını görüntü üzerine uygulamak için eşitlik 6 kullanılmaktadır.

$$
f(x, y)= \begin{cases}a x, & 0 \leq x \leq x_{1} \\ b\left(x-x_{1}\right)+y_{x_{1}}, & x_{1} \leq x \leq x_{2} \\ c\left(x-x_{2}\right)+y_{x_{1}}, & x_{2} \leq x \leq M\end{cases}
$$

Eşitlik 6'da $\mathrm{f}(\mathrm{x}, \mathrm{y}), \quad$ PLF yönteminin çıktısını oluşturmaktadır. a, b, c ve d değişkenleri doğrusal parçaların terimleri olup eğimleri belirtmektedir. $\mathrm{x}_{1}$ ve $\mathrm{x}_{2}$ değiş̧kenleri giriş görüntüsünün 0-255 aralığındaki sınır değerleridir. M terimi ise giriş görüntüsündeki en yüksek piksel değerini ifade etmektedir. Böylece tüm alana dağılmayan görüntülerin analizini sadece ilgili alan içinde yapılması sağlanmaktadır.

\subsection{ITU Dönüşümü (ITU Transformation)}

Zenginleştirme işlemi sonrasında RGB olarak yeniden oluşturulan görüntü, yeşilin baskın olduğu gri seviye renk uzayına ITU standardı ile dönüştürülmektedir. Bu dönüşüm için eşitlik 7 kullanılır. Bu eşitlikte $R, G$ ve $B$ ilgili pikselin sahip olduğu renk bilgilerini içeren değerlerdir. Bu değerler ile pikselin sahip olacağı gri seviye değeri, pikselin renk değerlerinin ağırlıklı ortalaması ile hesaplanır. Ağırlıklı ortalamada yeşil değeri daha baskın kullanıldığından, daha geniş bir gri seviye kontrast aralığı elde edilmektedir. Böylece düşük kontrasta sahip görüntüler üzerinde algoritmanın etkin çalışmasına katkı sağlanmaktadır.

$\mathrm{Gr}=(213 \times \mathrm{R}+715 \mathrm{xG}+72 \times \mathrm{B}) / 1000$

\subsection{Bölütleme (Segmentation)}

Gri seviye renk uzayına dönüştürülen 8 bitlik görüntü, MRA, K-Ortalalamalar ve BEM algoritmaları kullanılarak oluşturulan hibrit yapı ile çok seviyeli olarak bölütlenmektedir. $\mathrm{Bu}$ hibrit yapı MRA oluşumuyla başlamaktadır. Oluşturulan MRA üzerinde 3 küme merkez noktası K-Ortalamalar ile belirlenmektedir. Son olarak BEM algoritmasiyla pikselin hangi kümeye dahil edileceği kararı verilmektedir.

\subsubsection{Markov Rastsal Alan Oluşumu (Generating of Markov Random Field)}

MRA modeli, olasılık teorisini baz alarak görüntü içerisindeki uzamsal bağımlılıkların incelenmesine olanak sağlar. $\mathrm{Bu}$ bağımlılıkları belirlerken MRA yapısı, iki durumu belirginleştirir. İlk durum resim içerisinde yer alan nesnelerin yerlerinin belirlenmesidir. İkinci durum ise bu nesnenin doku özelliklerinin içerikle olan bağlantılı örüntülerin önsel olasılıklarıdır. $\mathrm{Bu}$ durum eşitlik 8 kullanılarak hesaplanir.

$P(y)=\frac{1}{z} e^{(-U(y))}$

Eşitlik 8'de ifade edilen $\mathrm{P}(\mathrm{y})$ önsel olasılık Gibbs dağılımı niteliğine sahiptir. $Z$ normalleştirme sabitini göstermekte olup normalizasyon sabiti olarak adlandırılır. Önsel enerji fonksiyonu olan U(y) ise olası tüm kliklerin potansiyellerinin toplamından oluşmaktadır. $\mathrm{Bu}$ şartlar sağlandığında eşitlik 8'de elde edilen $\mathrm{P}(\mathrm{y})$ olasılık değeri bir sinıfa ait Gauss dağılımının parametrelerine bağımlı olmalıdır. $\mathrm{Bu}$ durum eşitlik 9 ile hesaplanır. 
$P(x \mid y, \theta)=\prod_{i}^{n} p\left(x_{i} \mid y_{i}, \theta_{y_{i}}\right)$

Önsel olasılıklar MRA'nın sahip olduğu nesnel fonksiyonların, uygun değerlerle çözümünü sağlamak için istatistiksel olarak karar verici ve son durumu kestirici yöntemlerden biri olan BEM bu çalışmada tercih edilmiştir. $\mathrm{Bu}$ algoritmanın çalışacağı sınır değerlerinin belirlenmesinde ise K-Ortalamalar tercih edilmiştir.

\subsubsection{K-Ortalamalar ile Markov Rastsal Alanının} Kümelenmesi (Clusring of Markov Random Field with KMeans)

Bölütleme adımında MRA yapısı ilk olarak KOrtalamalar algoritması ile kümelenir. Algoritmanın ilk adımında, her bir K kümesi için bir adet başlangıç noktası rastsal olarak tanımlanır. Sonraki adımda, yapılan her bir iterasyon ile bu küme bilgileri güncellenir. $\mathrm{Bu}$ güncelleme işleminde her bir sınıfın ya da kümenin piksellerinin ortalama değeri bulunur. Diğer piksel değerlerinin öklit mesafeleri hesaplanır ve yakın olan veriler gruplanır. Böylece her bir kümenin sınırları oluşur. Güncel bilgiler ışığında, bir sonraki iterasyon ile ortalama değerleri tekrar bulunarak küme bilgileri güncellenir. Dolayısıyla her bir iterasyonda, $\mathrm{K}$ kümelerinin ortalamaları bulundukları özellik uzayı verilerinin ağırlıklı olduğu bölgeye doğru yaklaşacaktır.

$\mathrm{Bu}$ işlemi gerçekleştirmek için eşitlik 10'daki karşılaştırma işlemi yapılır. Bu karşılaştırma işleminin ardından piksel ilgili kümeye dahil edilir.

$\mathrm{x} \in \mathrm{C}_{\mathrm{j}}(\mathrm{k})$ eğer $\left\|\mathrm{x}-\mathrm{z}_{\mathrm{j}}(\mathrm{k})\right\|<\left\|\mathrm{x}-\mathrm{z}_{\mathrm{i}}(\mathrm{k})\right\|$

Eşitlik 11'deki ifade ile kümenin elemanları kullanılarak küme merkezi $\mathrm{z}(\mathrm{k})$ güncellenir. $\mathrm{Bu}$ durum iterasyon sayısının (m) sonuna kadar devam eder. Böylelikle yeni küme merkezi $\mathrm{z}_{\mathrm{j}}(\mathrm{k}+1)$ elde edilir.

$z_{j}(k+1)=\frac{1}{N_{j}} \sum_{x \in c_{j}(k)}^{m} x_{i}, j=1,2, \ldots ., K$

2.5.3. Beklenti Enbüyüklemesi Metoduyla Bölütleme (Segmenation with Maximum Expectaion Method)

MRA yapısı oluşturulup K-Ortalamalar ile küme merkezleri belirlendikten sonra En Büyük Sonsal Olasılık (EBSO) yöntemi ile MRA üzerinde etiketleme işlemi yapılır. EBSO yönteminin matematiksel yapısı eşitlik 12'de verilmiştir.

$\mathrm{y}=\operatorname{argmax}_{\mathrm{y}}\{\mathrm{P}(\mathrm{x} \backslash \mathrm{y}) \mid \mathrm{P}(\mathrm{y})\}$.
Çalışılan görüntüde $\mathrm{x}=\left(\mathrm{x}_{1}, \mathrm{x}_{2}, \ldots, \mathrm{x}_{\mathrm{n}}\right)$ kümesinde her bir $\mathrm{x}_{\mathrm{i}}$ piksel ifadesi bir yoğunluk değerini göstermektedir. $\mathrm{Bu}$ görüntü içinde yer alan her bir pikselin etiketine ait olan ifade ise $\mathrm{y}_{\mathrm{i}}\left(\mathrm{y}=\mathrm{y}_{1}, \mathrm{y}_{2}, \ldots, \mathrm{y}_{\mathrm{n}}\right)$ gibi küme değerlerini almaktadır.

Piksel değerinin hangi kümede yer alacağını belirlemek için eşitlik 12'deki EBSO algoritmasına başvurulur. MRA-EBSO yöntemi kullanılırken uzamsal komşulukların birbirine etkisinin belirlenmesi gereklidir. $\mathrm{Bu}$ işlem için BEM algoritması kullanılır. BEM algoritmasının temelinde iteratif bir yapı bulunmaktadır. Gauss dağılımında kullanılan $\theta$ parametresi, kümenin başlangıç koşulları için ilk iterasyon adımını oluşturur.

Beklenti adımında t. yinelemede $\theta^{t}$ koşullu Q olasılığ eşitlik 13 ile hesaplanır.

$Q\left(\theta \mid \theta^{t}\right)=\sum P\left(y \mid x, \theta^{t}\right) \ln P(y \mid x, \theta)$

Enbüyükleme adımında ise hesaplanan Q olasılık değerlerinden en büyüğü son değer olarak alınarak pikselin dahil olacağı sınıf belirlenir. Her bir iterasyon sonucu güncelleme yapılarak ilgili piksel siyah ya da beyaz olan bir sınıfa dahil edilip bölütleme işlemi sonlandırılır. $\mathrm{Bu}$ yapı çalışmada küme merkezlerini içeren belirli sınır değerleri içerisinde çalıştırılır. Böylelikle BEM algoritması MRA üzerinde 3 farklı sınır değeri için 3 farklı bölütleme sonucu üretir. Elde edilen 3 farklı bölütleme sonucu klasik toplama ile toplanarak ROI'ler oluşturulur.

\section{6. Öznitelik Çıkarımı (Feature Extraction)}

Öznitelik çıkarım adımında istatistik ve şekilsel analiz parametreleri ve bu çalışmada geliştirilen Cnt Faktör ve Sc Faktör bileşenleri kullanılmıştır. Bölütleme adımı sonrası elde edilen ROI'lerin ilk olarak ortalama, standart sapma, varyans ile bu varyans ifadesinin türevi bilgilerini içeren istatistiksel öz nitelik vektörü oluşturulur. Sonrasında ROI'lerin şekil yapısı ile ilgili olan yuvarlaklık, doygunluk, alan, düzgünlük, form faktör ve parçalanma miktarı öz nitelikleri hesaplanır.

Sınıflandırmada kullanılacak öznitelik vektörünün oluşturulmasında ikili bağımlı değişkenlerin saflık derecesine karar vermek adına Gini Katsayısı Ölçütü tercih edilmiştir. $\mathrm{Bu}$ yöntem özellikle bir sıklık dağılımının eşitsizlik miktarını ölçmede kullanılır. Hesaplanan katsayı, her özniteliğe ait ölçümün farklı sınıflara dağılımında yakınlık söz konusu ise sıfıra yaklaşır.

Diğer taraftan sadece bir sınıfa doğru dağılım olduğunda katsayı bire yaklaşır.

$\mathrm{Bu}$ durumda bir t özniteliği için, Gini katsayı indeksi olan $\mathrm{f}(\mathrm{t})$ fonksiyonu eşitlik 14 ile belirlenmektedir. 


$$
g(t)=\sum_{j \neq 1}^{2} P(j \backslash t) . P(i \backslash t)
$$

Eşitlik 14'te i ve j, bağımlı değişkenin farklı siniflarıdır. $\mathrm{Bu}$ siniflar ikili ihtimaller barındırmaktadır. Bunlar var veya yok olarak isimlendirilirler. $\mathrm{Bu}$ durumda oluşan indeksteki her bir sonuç, işlemin sonunda sadece bir sınıfa ait olmaktadır. Böyle bir durumda işlem sonlandırılır ve indeks değeri sıfıra eşitlenir. Bir özniteliğin karar verici olması adına en iyi kestirimin yapılacağ bağımsız olan değişkeni elde etmek için bağımsız değişken seti kullanılır ve bu ifadelerin her biri tek tek değerlendirilir. Değerlendirme sonucu elde edilen değerlerdeki en büyük azalmayı sağlayan en iyi değere sahip olan sonuç seçilir. Öznitelik vektöründe yer alan her bir $\mathrm{t}$ ifadesinde, bu öznitelik bilgisinin aday karar vericisi olan $s$ ifadesi hem doğru taraf ayrımını ( $\left.\mathrm{t}_{\mathrm{r}}\right)$ hem de yanlış taraf ayrımını $\left(\mathrm{t}_{\mathrm{w}}\right)$ gerçekleştirir. Bu durum eşitlik 15 ile ifade edilir.

$\vartheta(s, t)=f(t)-P_{r} g\left(t_{r}\right)-P_{w} g\left(t_{w}\right)$

Eşitlik 15'te $\mathrm{P}_{\mathrm{r}}$ şartın doğru olması durumundaki bağımlı $\mathrm{t}$ özniteliğinin sınıflandırma başarı sonuçların oranını verirken, $P_{w}$ şartın sağlanmadığı yanlış tarafındaki $\mathrm{t}$ özniteliğinin sonuçlarını ifade etmektedir. Böylece her bir güncel durum, normal şartlarda oluşan $\mathrm{f}(\mathrm{t})$ ifadesinden çıkarılarak 0-1 arası bir değer hesaplanır. Bu durum tüm öznitelik bilgileri için gerçekleştirilir. Vektördeki tüm ifadelerde ikili s ifadesi bir aday $\mathrm{S}$ seti içinde ifade edilir. Bu durum ilk öznitelik olan $t_{1}$ den başlayarak her bir ayırıcı $s^{*}$ '1n tüm ihtimalleri dahilindeki S'ler arasındaki azalma değeri ile aranmaktadır. Böylelikle her bir sonuç, i kadar alt sonuca ayrılmaktadır. Tekrarlamalı bölme algoritması ile homojen bir denge sağlanana kadar veya sadece bir durumu ifade eden tek bir sinıf kalana kadar bu süreç devam etmektedir. Vektör içerisindeki her bir özniteliğin değişmez bir sonuca gelmesi ile Gini analizi sonlandırılır. Bunu sağlamak için eşitlik 16 kullanılmaktadır.

$\vartheta\left(s^{*}, t_{1}\right)=\max \left(\vartheta\left(s, t_{1}\right)\right)$

Çalışmada gini analizi ile elde edilen 5 farklı öznitelik bilgisi kullanılmıştır. Bunlar hücre alanının piksel sayısı $\left(\mathrm{f}_{1}\right)$, Cnt Faktör, çarpıklık $\left(\mathrm{f}_{2}\right)$, Sc Faktör ve düzgünlük $\left(\mathrm{f}_{3}\right)$ bilgileridir.

Bölütleme adımı sonrasında elde edilen ROI içerisinde yer alan piksel sayısı, alan bilgisini ifade etmektedir. Alan bilgisini hesaplamak için eşitlik 17 kullanılır.

$f_{1}=m \cdot n$
Eşitlik 17 'de $f_{1}$ ifadesi ROI'nin piksel sayısını ifade etmektedir. $m$ ve $n$ değerleri ise görüntünün yatay ve dikey piksel sayısıdır. Çarpıklık parametresi, ortalama değer etrafındaki verilerin asimetriklik ölçüsünü ifade eder. Bu ölçü, üç istatistiksel bilgiye bakılarak tahmin edilebilir. $\mathrm{Bu}$ bilgiler mod, medyan ve ortalama bilgileridir. $\mathrm{Bu} 3$ bilginin içinde olduğu çarpıklık özniteliğinin hesaplanması için eşitlik 18 kullanılır.

$$
\begin{aligned}
& \mathrm{f}_{2}=\frac{1}{(\mathrm{mn}-1) \cdot \frac{1}{n-1}{\sqrt{\sum_{i}^{n}\left(x_{i}-f_{1}\right)^{2}}}^{3}} \sum_{\mathrm{i}}^{\mathrm{m}} \sum_{\mathrm{j}}^{\mathrm{n}}(\mathrm{I}(\mathrm{i}, \mathrm{j})- \\
& \left.\frac{1}{m n} \sum_{i}^{m} \sum_{j}^{n} I(i, j)\right)^{3}
\end{aligned}
$$

Eşitlik 18 'de $\mathrm{f}_{2}$ ifadesi çarpıklık miktarının ölçütüdür. $\mathrm{Bu}$ parametre, -1 ile 1 arası bir değer alır. Eğer ortalamadan sol tarafa doğru bir kayma varsa negatif bir bilgi elde edilir. Diğer yandan sağ tarafa doğru bir kayma varsa pozitif bir değer elde edilir.

Bu çalışmada geliştirilen Cnt Faktör ve parametreleri, Şekil 2'de ifade edilmiştir. Şekilde hücre görüntüsünün merkez noktasından $90^{\circ}$ 'lik açıyla ayırt noktalara çizilen iki doğru bulunmaktadır. Bu doğrulardan her birinin siyah noktalardan geçişi ile oluşan değerle beyaz noktalardan geçişi ile oluşan değerin birbirine oranıyla $t_{1}$ ve $t_{2}$ değerleri elde edilir. $\mathrm{Bu}$ işlemde, siyah noktalar çekirdek bilgilerini ifade ederken beyaz noktalar da sitoplazma bilgilerini ifade etmektedir. Böylelikle her bir doğru için bir oran hesaplanır. $\mathrm{Bu}$ oranın matematiksel ifadesi eşitlik 19'da ifade edilmiştir. Eğer bu değerlerden her ikisi ya da sadece birisi 1 'den küçük ise, $t_{1}$ ve $t_{2}$ değerleri birbirinden çıkarılarak mutlak değeri alınır. Diğer taraftan her ikisi de 1'den büyükse bu iki değer toplanır. Bu katsayı ile şeklin yuvarlak olup olmadığ ve ROI'nin yüzeyinin karmaşıklığı belirlenir. $\mathrm{Bu}$ parametre özellikle nötrofil ve ezonofil hücrelerinin diğer hücrelerden ayırt edilmesinde etkin rol oynadığ 1 yapılan deneyler sonucu elde edilmiştir.

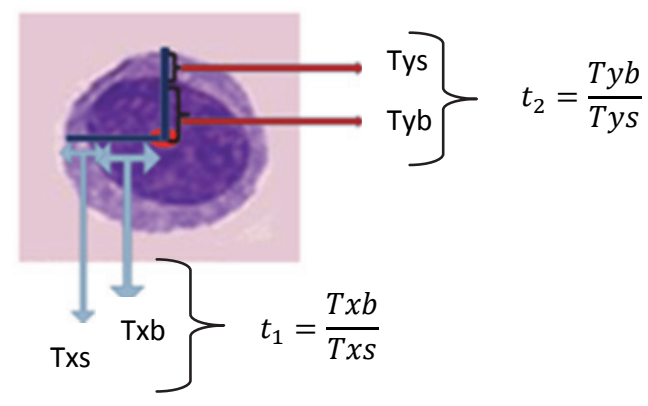

Şekil 2. Cnt Parametresi (The Cnt Parameter)

$C n t=\left\{\begin{array}{cl}\left|t_{1}-t_{2}\right|, & \text { Eğer } t_{1} \text { veya } t_{2}<1 \\ t_{1}+t_{2}, & \text { Eğer } t_{1} \text { ve } t_{2} \geq 1\end{array}\right\}$ 
Bu çalışmada geliştirilen diğer bir öznitelik bilgisi ise Sc Faktör'dür. Bu bilgi ise çok seviyeli bölütleme işlemi sonrası, hücrenin çekirdek ve sitoplazma bilgilerinin ayrı ayrı düzenlenmesi sonucu bu iki alana ait piksel sayılarının birbirlerine oranı ile elde edilir. $\mathrm{Bu}$ oran çekirdeğin sitoplazmada ne kadar yer kapladığını gösterir. Eşitlik 20 ile Sc Faktör öznitelik bilgisi elde edilir.

$\mathrm{Sc}=\frac{\sum_{\mathrm{i}}^{\mathrm{m}} \sum_{\mathrm{j}}^{\mathrm{n}} \operatorname{St}(\mathrm{i}, \mathrm{j})}{\sum_{\mathrm{i}}^{\mathrm{m}} \sum_{\mathrm{j}}^{\mathrm{n}} \operatorname{Ck}(\mathrm{i}, \mathrm{j})}$

Eşitlik 20'de St ifadesi, sitoplazmaya ait pikselleri ifade eder. Şekil 2'de açık mor renkli alanlarla gösterilir. Diğer taraftan Ck ifadesi ise çekirdeğe ait olan pikselleri ifade eder ve Şekil 2'de koyu mor olan alanlar ile gösterilir.

Düzgünlük özniteliği, bir alan içerisindeki piksel değerlerinin hangi ölçüde birbiriyle benzerlik gösterdiğini ifade eder. Standart sapma ile ilişkilendirilerek hesaplanan bu öz niteliğin matematiksel ifadesi eşitlik 21 'de gösterilmiştir.

$f_{3}=1-\frac{1}{1+\frac{1}{n-1} \sqrt{\sum_{i}^{n}\left(x_{i}-\frac{1}{m n} \sum_{i}^{m} \sum_{j}^{n} I(i, j)\right)^{2}}}$

Eşitlik 21'de $f_{3}$ ifadesi, düzgünlük miktarını göstermektedir. Piksellerin yoğunluk bilgileri göz önüne alınarak oluşturulan dizideki değerlerin birbirine yakın olması düzgünlük bilgisini sıfıra yaklaştırır. Diğer taraftan bu değerlerin dağılımı fazlalaştığında, bu değişken bire yaklaşır. Şekil 2'deki görüntünün düzgünlük özniteliği hesapladığında bire yakın bir değer elde edilir. Bu durum, resim içerisinde farklı özelliklere sahip alanların olduğunun göstergesidir.

2.7. Olasılıksal Yapay Sinir Ağları ile Sinıflandırma (Classification with Probabilistic Neural Network)

Olasılıksal yapay sinir ağları (OYSA), sınıflandırma problemlerinde kullanılan bir yapay sinir ağ modelidir. Sistemin temel çalışma prensibi Bayes karar verme kurallarına dayanır. Bayes kuralı sadece tek bir bölüm olarak kullanılırken, OYSA yapısını çok katmanlı bir biçimde kullanmak mümkündür. $\mathrm{Bu}$ katmanlar sırasıyla giriş katmanı, örüntü katmanı, aktivasyon fonksiyonu katmanı ve çıkış katmanıdır. Katmanlara ayrılmış OYSA yapısı Şekil 3'te görülmektedir [20].

Şekil 3 incelendiğinde OYSA yapısının ilk adımının giriş katmanı olduğu gözlemlenir. $\mathrm{Bu}$ adımda, görüntüden elde edilen öznitelikleri içeren vektör bilgileri kullanılır. $\mathrm{Bu}$ vektörde yer alan ve sinıflandırmada kullanılacak öznitelik sayısı kadar giriș düğümü kullanılır. OYSA giriş vektörü literatürde $\mathrm{P}$ vektörü olarak isimlendirilir. $\mathrm{P}$ vektöründeki $\mathrm{n}$ tane eleman her bir giriş bir düğümüne denk gelecek şekilde atanır. $\mathrm{Bu}$ atama işlemi eşitlik 22'de gösterilmiştir. Çalışmada 5 farklı öznitelik bilgisi P vektörünü oluşturmaktadır.

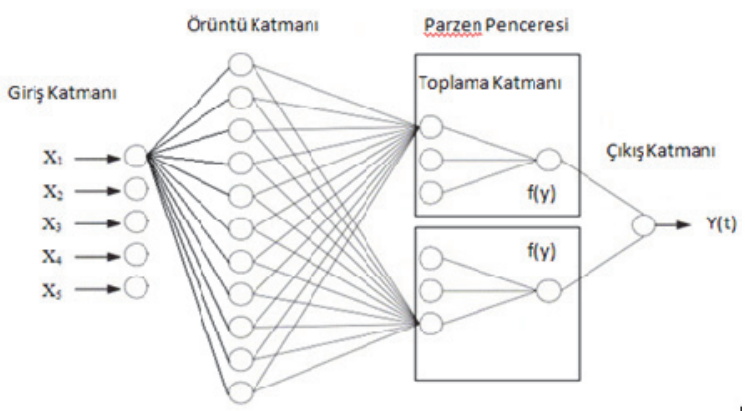

Şekil 3. Olasılıksal Yapay Sinir Ağları Genel Yapısı (General Structure of the Probabilistic Neural Network)

$\mathrm{P}=\left[\mathrm{P}_{1}, \mathrm{P}_{2}, \mathrm{P}_{3}, \mathrm{P}_{4}, \mathrm{P}_{5}\right]$

Her bir öznitelik bilgisinin bir düğüme atanmasıyla OYSA yapısının giriş bölümü eşitlik 23'teki gibi elde edilir. P vektöründeki veriler $0-20$ arasına normalize edilerek $\mathrm{x}$ giriş bilgisi olarak OYSA yapısına uygulanmıştır.

$\mathrm{x}=\left(\mathrm{x}_{1}, \mathrm{x}_{2}, \ldots \ldots, \mathrm{x}_{5}\right)$

Giriş aşamasındaki atama işleminin ardından bu düğümlerdeki değerler örüntü katmanında yer alan nöronlara aktarılır. Bu katmandaki her bir nöron yapısı, eğitim işlemi sonucu oluşur ve eğitimle ilgili matematiksel örüntüleri barındırır. Eğer eğitim aşamasında 75 farklı olasılık var ise bu katmanda 75 farklı nörondan oluşan bir örüntü bulunur. Örüntü katmanı nöronları barındırır ve OYSA yapısının ikinci ve üçüncü katmanlarını oluşturur. Bu katmanda yer alan her bir nöron yapısında iki yönlü çalışan bir fonksiyon mevcuttur. Bu fonksiyon bir yönüyle giriş vektörü olan P'ye bağliyken diğer yönüyle aktivasyon katmanına bağlıdır. Giriş vektörü $P$ yönünde gerçekleştirilen eğitim işleminde, örüntü katmanındaki her bir nöron ile giriş vektörü arasındaki öklit uzaklığının karesi hesaplanır. 3. adım olarak isimlendirilen ve dağılım ölçütüne göre üssel bir çıkış sağlayan bölüm aslında fonksiyonun ikinci yönüdür. Bu noktada hesaplanan uzaklık değeri üssel olarak dağılım ölçütünün karesi ile oranlanarak nöronun çıkış değeri hesaplanır. Dağılım değeri her bir eğitim adımının sonucunda oluşan ifadedir ve eşitlik 24'te gösterilmiştir.

$f=e^{-\sum_{i=1}^{p} \frac{\left(x_{i}-x_{r, i}\right)^{2}}{2 \sigma_{i}^{2}}}$

$\mathrm{Bu}$ eşitlik nöronun matematiksel yapısını ifade eder. $\mathrm{x}$ vektörüne ait veriler örüntü katmanındaki her bir nörona iletilir ve eşitlik sonucu elde edilir. Nöronlardan gelen sonuçlar, eğitim sonucu 
oluşturulan Şekil 4'teki gibi gauss eğrisine ve öklit uzaklıklarına göre hesaplanarak toplamı alınır.

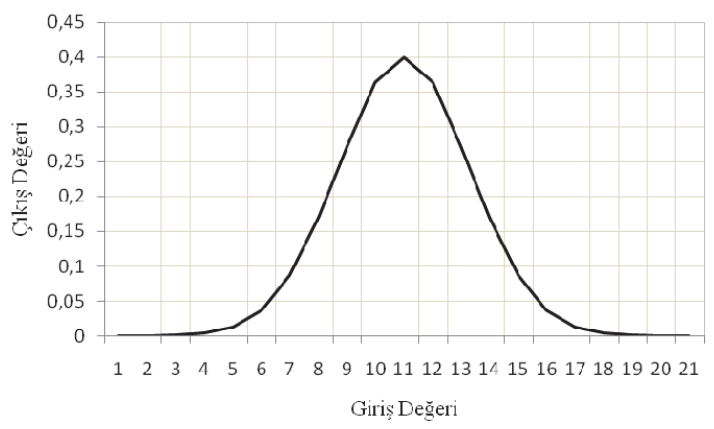

Şekil 4. OYSA Eğitim Sonucu Oluşan Gauss Dağılım Grafiği (Gauss Function Graph of the Trained Probabilistic Neural Network)

Eşitlik 24'te $\mathrm{x}_{\mathrm{i}}$ giriş ifadesini, $\mathrm{x}_{\mathrm{ri}}$ ise eğitim sonucu oluşan sonucu ifade eder. $\mathrm{Bu}$ iki değerin farkının karesi öklit uzaklığıdır. $\sigma$ ifadesi gauss dağılım ölçütünü verirken $\mathrm{p}$ örnek sayısını ifade eder. $\mathrm{Bu}$ fonksiyon aynı zamanda parzen penceresi olarak ta isimlendirilmektedir. $\mathrm{Bu}$ yapı gauss fonksiyonu özelliğini taşıdığından lineer olmayan bir yapıdadır. $\mathrm{Bu}$ lineer olmayan yapı ile ilgili yayılma miktarı, eşitlik 24'te ifade edilen fonksiyonun çıkışı, sınıflandırmada etkin rol oynar.Eğitim sonucu oluşan dağılım ile elde edilen dağılımın ne kadar örtüştüğü bu parzen pencere yapısı sonucu ortaya konur. Elde edilen sonuçlar 4. aşama olan çıkış düğümlerini içeren bölüme aktarılır. Bu bölümde Bayes kuralına göre, giriş vektörüne ait örtüşme miktarının sayısal değeri her bir sınıf için ayrı ayrı hesaplanır.Hesaplanan bu değerler birbirleriyle karşılaştırılarak çıkış katmanında yer alan $y_{i}$ çıkış değerleri eşitlik 25 'teki kurala göre üretilerek sınıflandırma işlemi sonuçlandırılır.

$y_{i}=\left\{\begin{array}{lll}1 & \text { eğer } & g_{i}(x)>g_{j}(x) \\ 0 & \text { eğer } & g_{i}(x)<=g_{j}(x)\end{array}\right\}$

Sonuç olarak her bir nörondan çıkış katmanına gelen ifadeler birbiriyle karşılaştırılarak eğitim adımı sonucu oluşan ve karşılaştırma işlemi sonucu transfer fonksiyonunda en yüksek olasılığa sahip olan sınıfa bayes karar vericileri ile yerleştirilir. Böylece bu yüksek olasılıklı çıkış bilgisi 1 olurken, diğer olasılıklı çıkış bilgileri sıfır olur ve sınıflandırma işlemi gerçekleştirilir.

\section{DENEYSEL BULGULAR (EXPERIMENTAL RESULTS)}

Mikroskop ve kameradan elde edilen görüntünün $\mathrm{S}$ doygunluk matrisi, 2592x1944 çözünürlüğüne sahiptir. Bu görüntü matrisi, geliştirilen programın daha hızlı çalışması ve bu programın koşturulduğu yöntemiyle küçültülmüştür. Böylece görüntü 530x400 piksel boyutlarına indirgenmiştir. Sonrasında Şekil 5'te grafiksel yapısı ifade edilen PLF yöntemi, S görüntüsünün zenginleştirilmesinde kullanılmıştır. Böylelikle lökosit hücre alanları ile preparat arka planı, renk doygunluğu açısından zenginleştirilirken orta bölgede oluşturulan düşük bant ile yüksek bant arasındaki bölge, sabit bir değer etrafında toplanmıştır. $\mathrm{Bu}$ aşamada lökosit sitoplazma bilgilerinin oldukça fazla bir bölümü ile çekirdek piksel bilgileri daha belirgin hale getirilerek algoritmanın verimliliğine katkı sağlanmıştır. Şekil 5'te ifade edilen A ve B noktaları Otsu Metodu ile elde edilmektedir.

$\mathrm{Bu}$ metot ile preparat görüntüsündeki tüm piksellerin değerleri alınır ve bu değerlerin dağılım ölçütüne göre varyansları hesaplanır. $\mathrm{Bu}$ varyans değerlerine göre pikseller kümelenir. Böylelikle kümeleme hedefine ulaşılırken diğer taraftan iki sınıf arasındaki varyans, en büyük değere yaklaşmış olur. Bu durum aynı sınıfa ait dağılımın varyansını en küçük değere ulaştırır. Böylelikle görüntü üzerinde iki farklı sınıf elde edilmesini olanaklı kılan eşik değeri elde edilir. Eşik değeri Şekil 5 üzerinde C ile ifade edilmiştir.

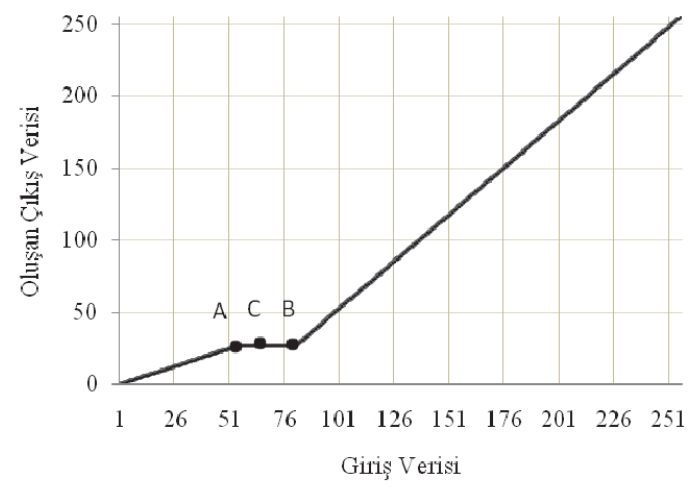

Şekil 5. Parçalı Doğrusal Filtre Yapısı (The Structure of The Piece-Wise Linear Filter)

Görüntünün histogramında yer alan bandın başlangıç (A) ve bitiş (B) değerleri, hesaplanan eşik değerine göre 0,83 ve 1,2 değerleriyle çarpılarak oluşturulur. Böylece 3 parçalı sistemin her bir parçasının sınır değerleri elde edilir. Bu noktadan sonraki adımda ise ilk parçadaki doygunluk değeri eğim ile çarpılarak azaltılırken, açı değeri de ters orantılı olarak artırılır. Orta kısımdaki bant üzerindeki doygunluk değerleri sabit bir değerde tutularak eritrosit hücrelerinin yerleri daha belirgin hale getirilir. Diğer taraftan üçüncü parça ile lökosit hücrelerinin bulunduğu alanların doygunluk değerleri eğim miktarında arttırılırken, açı değerleri ters orantılı olarak azaltılır.

PLF uygulanmadan önceki S doygunluk görüntüsünün görselleștirilmiş ilk hali Şekil 6a'da gösterilmiştir. $\mathrm{Bu}$ görüntüde işaretli alanda yer alan sitoplazma ve çekirdek bilgileri tam olarak görülmemektedir. 


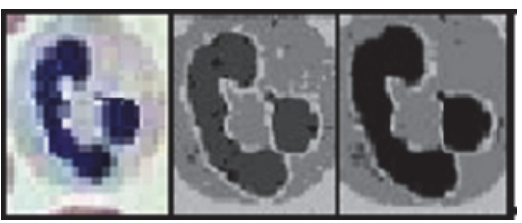

(a)

(b)

(c)

Şekil 6.a) Orijinal Hücre Görüntüsü (The Image of the Original Leukocyte) b) PLF olmadan S Doygunluk Görüntüsü (Saturation Image of S without PLF) c) PLF ile Zenginleştirilen S Doygunluk Görüntüsü (The Enhanced Saturation Image with PLF)

Diğer taraftan PLF yapısının $\mathrm{S}$ doygunluk parametresine uygulanmasından sonra Şekil 6b'deki görünüm elde edilir. Buradaki işaretli alan incelendiğinde sitoplazma ve çekirdek alanlarının tamamına yakını önişleme adımı sonucu elde edilmektedir. Şekil 6b'de bulunan hücrenin elde edilmesi aşamasında PLF, \%87 olarak ölçülen gerçeklik doğruluğunu \%98'e yükseltmiştir. Şekil $7 \mathrm{a}$ 'da laboratuardan alınan preparat örneği bulunmaktadır. Bu preparat görüntüsü, veritabanının $\mathrm{N}_{1}$ kategorisinde yer almaktadır. Preparatın RGB görüntüsü PLF ile işlenip tekrar oluşturulduğunda Şekil 7b'de gösterilen görüntü elde edilir. Bu noktada lökosit hücre bilgisi hem çekirdek hem de sitoplazma alanı bakımından daha belirgin hale gelmiştir.

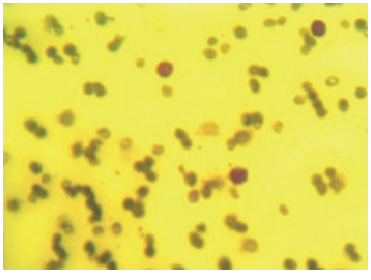

(a)

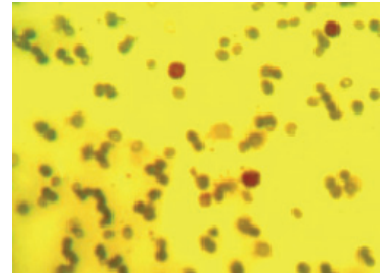

(b)
Şekil 7.a) Eğitim Araştırma Hastanesinden Alınan Preparat Görüntüsü(The Image of Blood Smear which is obtained from Education and Training Hospital-Turkey)b) Giriş Filtresinin Görüntüye Uygulanması Ve Sonucu (The Image of Reconstructed Smear which is processed by PLF)

Bölütleme aşamasında, zenginleştirilen görüntünün 8 komşuluklu MRA matrisi oluşturulmuştur. Bu matris, her bir pikselin komşularıyla olan ilişkilerini de belirttiği için 530x400x8 boyutlarındadır. Elde edilen bu matriste lökosit hücreleri, arkaplan ve eritrosit hücreleri olmak üzere üç ayrı hücreye ait bilgiler yer almaktadır.

$\mathrm{Bu}$ bilgilere bağımlı görüntünün histogramı elde edilmiştir. Çok seviyeli bir bölütleme yapıldığından elde edilen bu histogram bilgileri iki boyutlu bir matris biçimine dönüştürülerek, K-Ortalamalar algoritması ile kümelenmiştir.
Beş adımlık iterasyon işlemi sonunda üç ayrı kümenin merkezini ifade eden histogram bilgisi, şekil 8'de koyu noktalar ile gösterilmiştir. Bu merkez noktalar, BEM algoritmasının çalışma aralıklarının belirlenmesinde kullanılmıştır. İlk çalışan BEM arkaplan ve eritrosit alanlarını ayırt ederken ikinci çalışan BEM lökosit hücre sitoplazma alanlarını çözümlemektedir. Son çalışan BEM ise lökosit çekirdek alanlarının belirlenmesini sağlamaktadır.

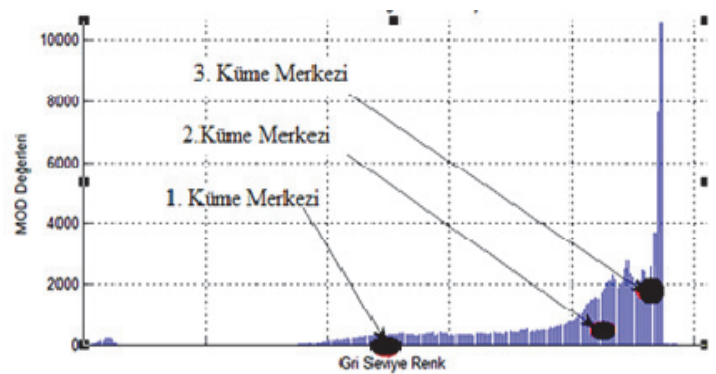

Şekil 8. K-Ortalamalar Algoritması Sonucu Tahmin Edilen Ortalama Değerlerin Dağılımı (The Clusters of the processed Image which is estimated by K-Means Algorithm)

Şekil 9a'da Utah Üniversitesi veritabanından alınan görüntü gösterilmektedir. Şekil 9b'de ise hibrit yapı tarafından bölütlenen lökosit hücreleri gösterilmiştir.

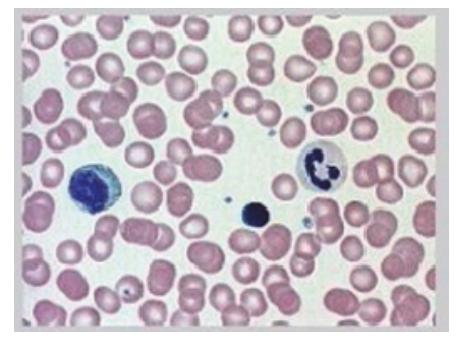

(a)

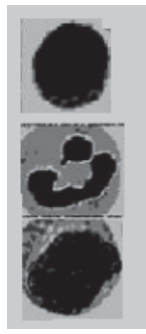

(b)
Şekil 9. a) Utah Üniversitesi Veritabanından Alınan Görüntü (The Image of Blood Smear obtained from Utah University Dataset) b) 3 Seviyeli Bölütlenmiş Hücrelerin Gösterimi (Segmented results with 3 levels)

Şekildeki hücrelerin, hücre çekirdekleri, sitoplazma bilgileri ve arkaplan alanı olmak üzere 3 seviyeli olarak bölütlenerek ROI yapısı oluşturulmuş hali gösterilmiştir. ROI'lerin elde edilmesinin ardından her bir ROI yapısının istatistiksel ve şekilsel öznitelikleri elde edilmiştir. Elde edilen öznitelik vektörü 34 farklı öznitelik bilgisini içermektedir. Bu vektörün gini analizi yapıldığında öznitelik vektöründeki öznitelik bilgileri 11 olarak elde edilmektedir. Çalışmada geliştirilen Cnt Faktör ve Sc faktör parametrelerinin eklenmesiyle öznitelik vektörü 36'ya yükselmiştir. Aynı şartlar geçerli olmak üzere tekrar gerçekleştirilen gini analiziyle 5 öznitelik bilgisi elde edilmiştir. Böylece gini analizi ile elde edilen 11 farklı öznitelik bilgisi, Cnt Faktör ve Sc 
Tablo 1. OYSA Eğitim Așaması Veri Seti Dağılımı (Training Dataset of the PNN)

\begin{tabular}{|c|l|c|c|c|c|c|}
\hline $\begin{array}{l}\text { Veri } \\
\text { Türü }\end{array}$ & Görüntü Kategorisi & Lenfosit & Nötrofil & Monosit & Ezonofil & Bazofil \\
\hline $\mathbf{N}_{\mathbf{1}}$ & Normal & 1 & 1 & 1 & 2 & 2 \\
\hline $\mathbf{N}_{\mathbf{2}}$ & Boyama Problemi olan Preparatlar & 8 & 8 & 4 & 4 & 4 \\
\hline $\mathbf{N}_{\mathbf{3}}$ & Işılandırma Problemi olan preparatlar & 8 & 8 & 4 & 4 & 5 \\
\hline $\mathbf{N}_{\mathbf{4}}$ & Utah Veri Seti & 4 & 3 & 1 & 2 & 1 \\
\hline \multicolumn{2}{|c|}{ Toplam } & $\mathbf{2 1}$ & $\mathbf{2 0}$ & $\mathbf{1 0}$ & $\mathbf{1 2}$ & $\mathbf{1 2}$ \\
\hline
\end{tabular}

Faktör özniteliklerinin eklenip tekrar analiz edilmesiyle 5'e düşürülmüştür. Bu bilgilerin her biri yapay sinir ağı yapısının daha verimli çalışması için 0-20 arasına normalize edilerek veritabanında yer alan her bir hücrenin öznitelik vektörü elde edilmiştir. Yapılan çalışmada 60 farklı hastaya ait preparat kullanılarak oluşturulan veritabanı yanında, karşılaşılabilecek ihtimalleri barındırması sebebiyle Utah Üniversitesi veritabanı da kullanılmıştır. Kendi oluşturduğumuz veritabanında yer alan preparatların görüntüleri farklı 1şıklandırma koșulları ile alınmış ve 308 preparat görüntüsü elde edilmiştir. Utah Üniversitesi veri setinden alınan hücrelerle beraber toplam 590 lökosit hücresi veritabanında bulunmaktadır. OYSA yapısı oluşturulurken elimizde var olan veritabanındaki lökosit hücre verileri, eğitim ve test aşaması verileri olarak iki gruba ayrılmıştır. Eğitim aşaması için \%13'lük bir hücre bölümü rastsal olarak seçilmiştir.

Bu veriler Tablo 1'de ifade edilen her bir kategoriden katıştırılarak elde edilmiştir. $\mathrm{N}_{1}, \mathrm{~N}_{2}, \mathrm{~N}_{3}$ ve $\mathrm{N}_{4}$ 'ten seçilen 21 lenfosit hücresi, 20 nötrofil hücresi, 10 monosit hücresi, 12 ezonofil hücresi ve 12 bazofil hücresi bilgileri olmak üzere toplamda 75 adet lökosit hücresinin öznitelik vektör bilgileri eğitim aşamasında kullanılmıştır. Her bir hücrenin 0-20 aralığına normalize edilmiş 5 farklı öznitelik bilgisi kullanılarak $5 \times 75^{\prime}$ lik bir eğitim veri matrisi oluşturulmuştur. Böylece her bir parametre, benzer biçime sahip gauss eğrisi yapısındaki parzen penceresine aktarılmaktadır. Bu eğrinin oluşması için veri setindeki her bir verinin hangi sınıfa dahil olduğu ön bilgisi, eğitim aşamasında yazılımsal olarak ifade edilmektedir. Böylece en başta OYSA yapısı, 5 sınıf olduğunun farkında olarak eğitim aşamasına başlayacaktır. Böylece her bir $\mathrm{x}$ giriş vektörünün hangi y çıkış sınıfına karşılık geleceği belirlenir. $\mathrm{Bu}$ belirleme işlemine başlamadan önce her bir eğitim seti barındırdıkları vektörlerle birlikte örüntü katmanı olarak ifade edilen nöronları oluşturur. Her bir eğitim vektörü bir nöron olacak şekilde organize edilir. Dolayısıyla toplam 75 nöron yapısı örüntü katmanını oluşturur. $\mathrm{Bu}$ adımın ardından her bir sınıfa ait bir parzen penceresi oluşturulur. Toplamda 5 farklı sınıf olduğundan her bir sınıf için bir parzen penceresi bulunmaktadır. Bu parzen pencerelerinin içerisine her bir sınıfa ait olan hücre verileri kullanılarak bir ortalama ve standart sapma değeri hesaplanır. Bu hesaplamanın ardından her bir sinifa ait parzen penceresi içerisinde yer alan nöron sayısı kadar gauss eğrileri oluşturulur. 5 farklı öznitelik bilgisi düşünüldüğünde bu pencere içerisinde 5 ayrı gauss eğrisi oluşacaktır. Sonuç olarak tüm bu eğrilerin ayrı ayrı ifade edildiği tek olan bu ortam parzen penceresidir. Yapılan deneylerde eğitim aşaması için seçilen 75 farklı hücre veri seti $\% 100$ başarı ile istenen sınıfa yerleştirilmiştir. Bu durum tablo 2'de ifade edilmiştir. Dolayısıyla her bir öznitelik veri seti en az bir sınıfa çakışma olmadan yerleştirilmiştir. Eğitim aşaması sonrasında oluşturulan OYSA yapısı, veri tabanında kalan diğer veriler ile test aşamasından geçirilmiştir. Hücrelere ait öznitelik verileri, eğitim aşamasında oluşturulan parzen pencerelerindeki gauss eğrilerine aktarılır.

Tablo 2. Eğitim Aşaması Sonucu OYSA Yapısı Sınıf Yerleşim Başarısı(The success of the Training of the PNN)

\begin{tabular}{|c|c|c|c|}
\hline $\begin{array}{c}\text { Hücre } \\
\text { Sınıfı }\end{array}$ & $\begin{array}{c}\text { Hücre } \\
\text { Sayısı }\end{array}$ & $\begin{array}{c}\text { Belirlenen } \\
\text { Sınıf }\end{array}$ & $\begin{array}{c}\text { Sinıflandırma } \\
\text { Başarısı }\end{array}$ \\
\hline Lenfosit & 21 & $\mathrm{~L}$ & $\% 100$ \\
\hline Nötrofil & 20 & $\mathrm{~N}$ & $\% 100$ \\
\hline Monosit & 10 & $\mathrm{M}$ & $\% 100$ \\
\hline Ezonofil & 12 & $\mathrm{E}$ & $\% 100$ \\
\hline Bazofil & 12 & $\mathrm{~B}$ & $\% 100$ \\
\hline Toplam & 75 & & $\% 100$ \\
\hline
\end{tabular}

$\mathrm{Bu}$ gauss yapılarının her birinin $\mathrm{x}$ eksenine gönderilen giriş bilgilerine karşılık y eksenindeki sonuçlar elde edilir.

Böylece her bir öznitelik bilgisine karşılık bir çıkış verisi üretilir. $\mathrm{Bu}$ veriler ile her bir gauss eğrisinin ne kadar örtüştüğü, eşitlik 24'ten elde edilen sonuç ile tespit edilir. Böylece her bir parzen penceresinin çıkış sonucu elde edilir. En yüksek olasılık değeri, ilgili sınıfa yerleştirilerek verilerin işlenmesi tamamlanır.

Test aşamasında, elimizde kalan verilerin \%87'lik bölümü kullanılmıştır. Bu aşamada kullanılan her bir kategoriye ait hücre sayıları Tablo 3 'te gösterilmiştir. Kullanilan hücre türlerinin $\mathrm{N}_{1}, \mathrm{~N}_{2}, \mathrm{~N}_{3}$ ve $\mathrm{N}_{4}$ kategorilerinden katılımı da yine bu tabloda belirtilmiştir. Test bölümünde toplam 479 hücreye ait vektörel bilgi bulunmaktadır. Bu hücrelerden, 237'si lenfosit hücresi, 109'u nötrofil hücresi, 55'i monosit 
hücresi, 59'u ezonofil hücresi ve 55'i de bazofil hücresidir. Test aşaması sonucu elde edilen sınıflandırma analizi Tablo 4'te ifade edilmiştir. Tabloda, veri setinde bulunan her bir hücre grubunun ve kategorisinin geliştirilen OYSA yapısındaki toplam hücre sayıları "T" belirteci ile ifade edilmektedir. "Y" belirteci ise veri setinde bulunan hücrelerin ilgili sınıflara doğru olarak kaç tanesinin yerleştiğini ifade ederken " $\mathrm{B}$ " belirteci ise yüzde olarak başarıyı göstermektedir. Toplam hücre sayısı ile başarılı olarak yerleşen hücre sayıları oranlandığında her bir hücre kategorisinde OYSA yapısının ne kadar başarılı olduğu gözlenmektedir. Sonuçlar incelendiğinde geliştirilen OYSA yapısı özellikle temiz hazırlanmış ve öznitelik bilgileri net olarak ortaya konmuş $\mathrm{N}_{1}$ kategorisinde yer alan 103 lökosit hücresinden 96's1 doğru sınıfa yerleştirmiştir. Bu kategorideki başarı oranı \%93 olarak ölçülmüştür. Boyama problemine sahip olan $\mathrm{N}_{2}$ kategorisindeki hücrelerin sinıflandırılmasında ise toplam 172 hücreden 158 tanesini doğru olarak OYSA tarafından doğru sınıfa yerleştirilmiştir. Bu noktadaki sınıflandırma başarısı $\% 92$ 'dir.

Tablo 3. OYSA Test Aşaması Veri Seti Dağılımı (The Test Dataset of the PNN)

\begin{tabular}{|c|c|c|c|c|c|}
\hline $\begin{array}{c}\text { Veri } \\
\text { Türü }\end{array}$ & $\mathbf{L}$ & $\mathbf{N}$ & $\mathbf{M}$ & $\mathbf{E}$ & $\mathbf{B}$ \\
\hline $\mathbf{N}_{\mathbf{1}}$ & 37 & 26 & 13 & 15 & 12 \\
\hline $\mathbf{N}_{\mathbf{2}}$ & 102 & 26 & 16 & 14 & 14 \\
\hline $\mathbf{N}_{\mathbf{3}}$ & 36 & 20 & 13 & 16 & 15 \\
\hline $\mathbf{N}_{\mathbf{4}}$ & 62 & 37 & 13 & 14 & 14 \\
\hline Toplam & 237 & 109 & 55 & 59 & 55 \\
\hline
\end{tabular}

Işıklandırma problemine sahip preparat görüntülerinin olduğu $\mathrm{N}_{3}$ kategorisinde ise bulunan 100 hücreden 86'sı tanesi doğru olarak bir sınıfa yerleştirilmiştir. $\mathrm{Bu}$ noktadaki başarı oranı ise \% 86'dır. Utah Üniversitesi veri tabanından alınan $\mathrm{N}_{4}$ sinıfında ise toplam 140 hücreden 132 tanesi doğru olarak ilgili sınıfa yerleştirilmiştir. Bu noktadaki başarı oranı ise \%92'dir. Yapılan deneyler sonucunda geliştirilen OYSA yapısı test bölümü için hazırlanan 515 lökosit hücresinden 472 tanesini doğru sınıfa yerleştirmiştir. Sistemin genel test başarısı ise $\% 91,65$ olarak ölçülmüştür.

\section{SONUÇLAR VE TARTIŞMA (RESULTS AND DISCUSSION)}

Otsu metoduyla dinamiklik kazandırılarak PLF ile zenginleştirilen görüntüde, lökosit hücreleri belirgin hale getirilmiştir. $\mathrm{Bu}$ durum tüm hücre alanının \%98'inin elde edilmesini sağlamaktadır. Geliştirilen yöntemin adımlar halinde çalıştırılmasıyla elde edilen sonuçlar şekil 10'da ifade edilmiştir. Şekil 10a'da eş zamanlı alınan görüntü yer almaktadır. Bu görüntünün doygunluk matrisi baz alınarak elde edilen görüntü Şekil 10b'de yer almaktadır. Şekil 10c'de ise PLF yapısıyla zenginleştirilen görüntü sunulmuştur. Tekrar RGB uzayına geri dönüldüğünde Şekil 10d'de gösterilen görüntü elde edilmektedir. Standart olarak gri seviye uzayına dönüşüm yapıldığında Şekil 10e'deki görüntü elde edilmektedir. Çalışmada ITU standardı kullanıldığında Şekil 10f'deki görüntü elde edilmektedir. Bölütleme adımı Şekil 10g'de gösterilen lökosit hücrelerinin elde edilmesiyle sonlandırılmaktadır. Sonrasında geliştirilen hibrit yapıyla bölütlenen lökosit hücrelerinin öznitelik analizi yapılmıştır. Bu analiz sonucu her bir hücrenin öznitelik vektörü elde edilerek veritabanı oluşturulmuştur. Bu çalışmada geliştirilen Cnt Faktör ve Sc Faktör ile öznitelik vektörünün eleman sayısı 5'e düşürülerek daha basit ve hızlı bir sınıflandırma işlemi gerçekleştirilmesine olanak sağlanmıştır. Elde edilen veri setinden rastsal olarak ayrılan \%13'lük veri seti grubu, OYSA'nın eğitim işleminde kullanılmıştır. $\mathrm{Bu}$ aşamada her bir öznitelik veri seti en az bir sınıfa çakışma olmadan yerleştirilmiştir. Eğitim sonucu elde edilen yapının, test aşamasında başarılı bir şekilde çalıştığı gözlenmiştir. Kaliteli ve özenli bir boyama ile hazırlanan preparat görüntülerini içeren Utah Üniversitesi veri seti ile yapılan çalışmada oldukça başarılı sonuçlar elde edilmesine karşın, günlük hayat uygulamalarına bakıldığında preparatların ve elde edilen görüntülerin oldukça karmaşık ve sıkıntılı olduğu gözlenmiştir. Bu durum uzmanların inceleme esnasinda fazla enerji harcamasına, zaman kaybına ve hata yapma riskine yol açmaktadır. Bu çalışmada geliştirilen yöntem tam otomatik yapısıyla bu tür sıkıntılı görüntüler üzerinde etkin çalışmış ve lökosit hücrelerinin $\% 91,65^{\prime}$ i doğru olarak sınıflandırmıştır.

Tablo 4. OYSA Test Așaması Değerlendirme Sonucu(The Test Result of the PNN)

\begin{tabular}{|c|c|c|c|c|c|c|c|c|c|c|c|c|c|c|c|}
\hline \multirow{2}{*}{$\begin{array}{l}\text { Veri } \\
\text { Türüi }\end{array}$} & \multicolumn{3}{|c|}{ Lenfosit } & \multicolumn{3}{|c|}{ Nötrofil } & \multicolumn{3}{|c|}{ Monosit } & \multicolumn{3}{|c|}{ Ezonofil } & \multicolumn{3}{|c|}{ Bazofil } \\
\hline & $\mathbf{T}$ & $\mathbf{Y}$ & B & $\mathbf{T}$ & $\mathbf{Y}$ & B & $\mathbf{T}$ & $\mathbf{Y}$ & B & $\mathbf{T}$ & $\mathbf{Y}$ & B & $\mathbf{T}$ & $\mathbf{Y}$ & B \\
\hline $\mathbf{N}_{1}$ & 37 & 36 & $\% 97$ & 26 & 24 & $\% 92$ & 13 & 12 & $\% 92$ & 15 & 13 & $\% 87$ & 12 & 11 & $\% 92$ \\
\hline $\mathbf{N}_{2}$ & 102 & 96 & $\% 94$ & 26 & 24 & $\% 92$ & 16 & 14 & $\% 88$ & 14 & 12 & $\% 86$ & 14 & 12 & $\% 86$ \\
\hline $\mathbf{N}_{3}$ & 36 & 33 & $\% 92$ & 20 & 17 & $\% 85$ & 13 & 11 & $\% 85$ & 16 & 13 & $\% 81$ & 15 & 12 & $\% 80$ \\
\hline $\mathbf{N}_{4}$ & 62 & 60 & $\% 97$ & 37 & 35 & $\% 95$ & 13 & 12 & $\% 92$ & 14 & 13 & $\% 93$ & 14 & 12 & $\% 86$ \\
\hline Toplam & 237 & 225 & $\% 95$ & 109 & 100 & $\% 92$ & 55 & 49 & $\% 89$ & 59 & 51 & $\% 86$ & 55 & 47 & $\% 85$ \\
\hline Başarı & & & & & & & & & & & & & & & \\
\hline
\end{tabular}




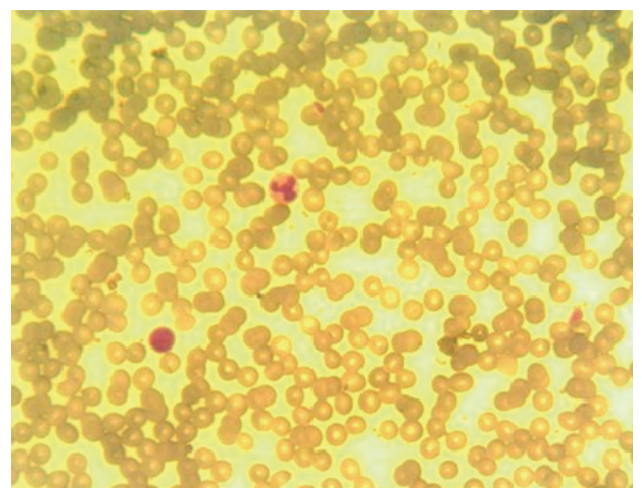

(a)

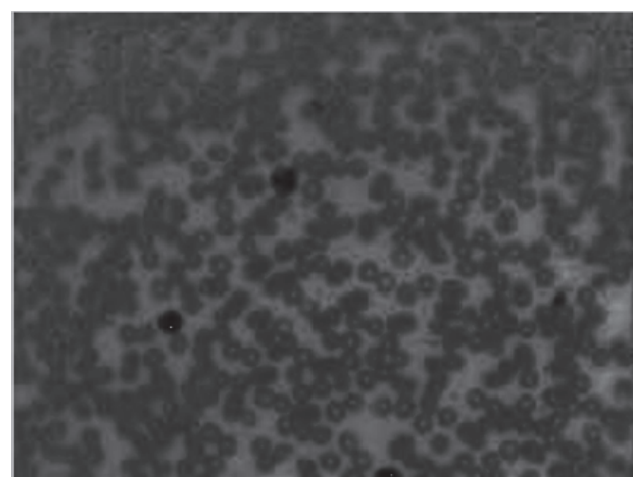

(c)

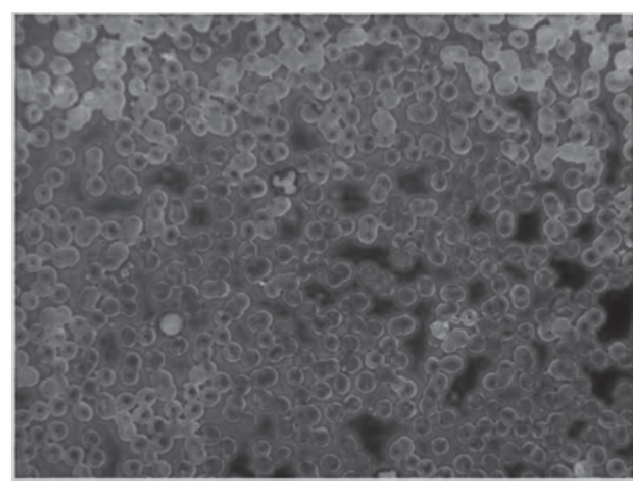

(e)

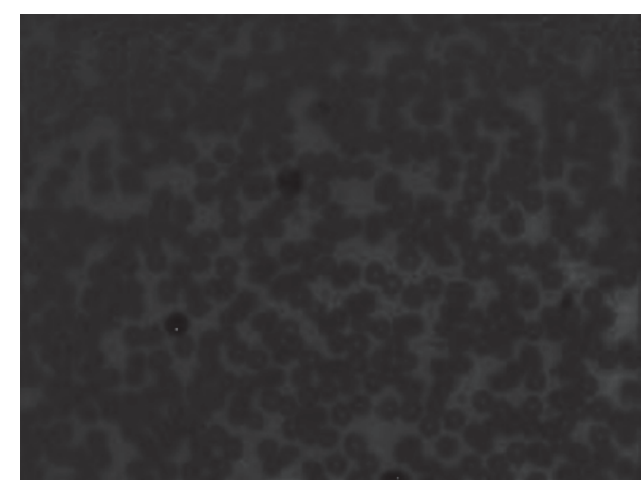

(b)

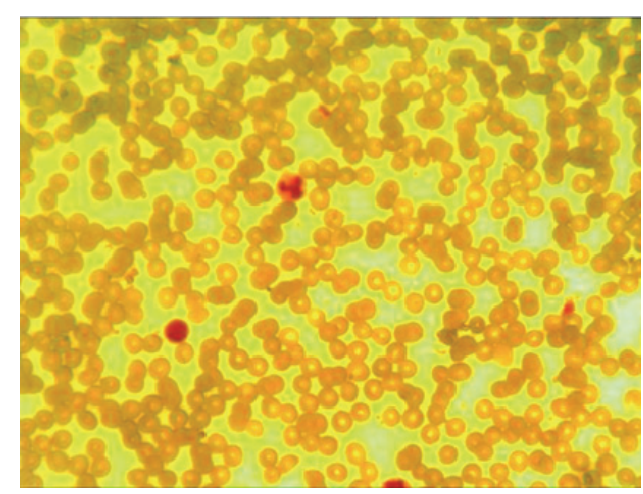

(d)

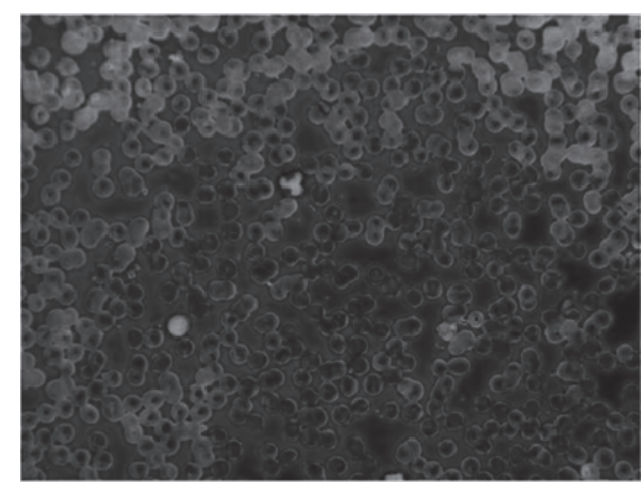

(f)

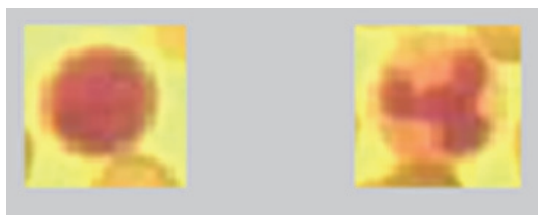

(g)

Şekil 10. a) Eğitim Araştırma Hastanesinden Alınan Preparat Görüntüsü (The Smear Image which is obtained from Education and Training Hospital) b) Doygunluk Bilgisini İçeren Görüntü (The Saturation Image of the Smear) c) Giriş Filtresinin Görüntüye Uygulanması Ve Sonucu (Applying Input Filtering and its Result) d) Zenginleştirilen Görüntünün RGB Görünümü (The RGB appearance of the Enhanced Image) e) RGB'den Gri Seviye Uzayına Standart Dönüşüm Uygulanan Görüntü (The Gray Level Image of the processed and enhanced Image) f) ITU Standardı ile Dönüşüm Uygulanan Görüntü (The Gray Level Image of the processed and enhanced Image with ITU Standard) g) Hücrelerin Görüntüden Alınarak Bölütlenmesi (The Segmented Leukocytes) 
Tablo 5. OYSA Test İşlemi Doğruluk Matrisi (Accuracy Matrix of the PNN)

\begin{tabular}{|l|c|c|c|c|c|}
\hline Doğruluk Matrisi & L & N & M & E & B \\
\hline Lenfosit & 225 & 4 & - & - & - \\
\hline Nötrofil & 4 & 100 & - & 5 & - \\
\hline Monosit & - & - & 49 & - & - \\
\hline Ezonofil & - & 3 & - & 51 & 1 \\
\hline Bazofil & - & - & - & 1 & 47 \\
\hline Sınıflanamayan & 8 & 2 & 6 & 2 & 7 \\
\hline Toplam & 237 & 109 & 55 & 59 & 55 \\
\hline
\end{tabular}

Çalışmanın eğitim ve test veri seti kullanılarak elde edilen OYSA yapısına ait olan doğruluk matrisi yapısı tablo 5'te ifade edilmiștir. $\mathrm{Bu}$ tabloda sınıflandırma işlemi sonrasında her bir hücre türünün toplam olarak 5 farklı sınıftan hangi sınıfa yerleştirildiği gösterilmektedir. $\mathrm{Bu}$ sonuçlar doğrultusunda test aşaması için oluşturulan veri setindeki toplam 237 lenfosit hücresinden $225^{\prime} \mathrm{i}$ doğru olarak lenfosit sınıfina dahil edilmiştir. Lenfosit hücrelerinden yanlış sınıflandırılan hücrelerden sadece 4 tanesi nötrofil sınıfina dahil edilirken, 8 hücre de üst üste gelme sebebiyle filtreleme adımından geçememiştir. $\mathrm{Bu}$ noktada en önemli katkı şekli bozulmuş, sitoplazması genişlemiş hastalık belirten 78 lenfosit hücresinin doğru olarak sınıflandırılmasıdır. Toplamda 132 hastalıklı hücreden sadece 12 tanesi algoritma tarafından yakalanamamıştır. Nötrofil hücrelerine bakıldığında ise 109 farklı nötrofil hücresinden 100 tanesi doğru olarak sınıflandırılmıştır. Yine hastalık belirtisi gösteren ve şekli oldukça bozuk hücrelerin lenfosit hücresine benzerliğinden dolayı 4 nötrofil, lenfosit hücresine benzetilirken 3'ü de ezonofil sınıfına dahil edilmiştir. Yine görüntünün dağılması sebebiyle 2 hücre, "Siniflanmayan" olarak etiketlenmiş ve sınıflandırılamayan hücre kategorisine dahil edilmiştir. Üçüncü tür lökosit hücresi olan monosit hücrelerinde ise 55 farklı hücrede 49 tanesi doğru olarak sınıflandırılmıştır. Diğer türlere göre oldukça büyük olan bu hücreler, görüntüdeki kenarlardan taşma ve diğer hücrelerle birleşme nedeniyle 6 tane hücre "Sinıflanamayan" hücre kategorisine dahil edilmiştir. Dördüncü tür olan ve analiz aşamasında oldukça az rastlanan ezonofil hücrelerinde, 59 ezonofil hücresinden 5 tanesi nötrofile benzetilirken 1 tanesi bazofile benzetilmiş 2 tanesi de "Siniflanamayan" kategorisine yerleştirilmiştir. Son sınıf olan ve yine analiz aşamasında oldukça az rastlanan bazofil hücresinin 55 tanesinden 47'si doğru olarak sınıflandırılmıştır. Bu hücrelerden 7 tanesi oldukça büyük ve düzensiz yapısından dolayı "Sınıflanamayan" sınıfına dahil edilmiş 1 tanesi de ezonofil sınıfına dahil edilmiştir. Sınıflanamayan kategorisi göz önüne alınmadığında çalışmada geliştirilen OYSA yapısının hücreleri doğru sınıfa yerleşme oranı \%96,3 olmaktadır.
Benzer yarı otomatik tasarlanmış çalışmadaki PLF yöntemiyle yapılan zenginleştirme işleminde, Utah Üniversitesi veritabanındaki özenle hazırlanmış görüntüler kullanılmıştır. Yapılan çalışma incelendiğinde özellikle granüllü hücrelerin zenginleştirme işlemi sonrasında oldukça parçalı olarak elde edildiği gözlemlenmiştir [22]. Tüm sistem olarak 5 farklı lökosit hücresini sınıflandıran benzer bir çalışmanın bölütleme adımında Gram-Schmidt ve snake algoritmaları kullanılmıştır. ROI'lerin elde edilmesinin ardından sınıflandırma işlemi Support Vector Machines (SVM) ve Multi-Level Perceptron (MLP) ile yapılmıştır. Bu algoritmaların giriş bilgileri olarak doku analizi sonucu elde edilen öznitelik vektörü kullanılmıştır. 10 farklı öznitelik bilgisi ile yapılan sınıflandırmada \%93'lük başarı elde edilmiştir [23]. Bu yapıda kullanılan veri seti hastalıklı hücreleri barındırmamaktadır. Ayrıca boyama ve ışıklandırma koşulları laboratuar ortamında hazırlanmış, günlük hastane ortamından alınan ve üzerinde iyileştirmeler yapılmamış veriler kullanılmamıştır

Benzer çalışmalarla birlikte değerlendirildiğinde bu çalışmada geliştirilen yöntem normal olan hücrelerle birlikte hastalıklı olan hücrelerde de çok etkili olarak çalışmaktadır. Ayrıca benzer bir sınıfa yerleştiremediği hücreleri rapor kısmında belirterek analiz edilemeyenler kategorisine (Sinıflanamayan) yerleştirebilmektedir. $\mathrm{Bu}$ durum uzmanların yorumuna birakılarak uzmana destekleyici bir yap1 sunmaktadır.

Ülkemizdeki hematoloji uzmanı sıkıntısı da göz önüne alındığında, uzmanların olmadığı durumlarda hücre sayılarının incelenmesiyle yönlendirme yapılarak erken teşhis anlamında önemli destek ve katkı sağlayacaktır.

\section{KAYNAKLAR (REFERENCES)}

1. Barth D., Hirschmann J.V., Anemia: In: Wintrobe's Atlas of Clinical Hemathology, Wolters Kluwer-Lippincott Williams \& Wilkins, Philadelphia, PA., 2007.

2. Glassy E.F., Color Atlas Of Hematology. An Illustrated Field Guide Based on Proficiency Testing, College of American Pathologists, IL, Northfield,1998.

3. Kasım Ö., Kuzucuoğlu A.E., Identification of Blood Cell Using Matlab Tools, Master Tezi, Marmara Üniversitesi, Fen Bilimleri Enstitüsü 2008.

4. Harousseau J. L., Flandrin G., Tricot G., Brouet J.C., Bernard M," Malignant Lymphoma Supervening In Chronic Lymphocytic Leukemia And Related Disorders. Richter's Syndrome: A Study of 25 Cases", Cancer, Cilt 48, 1302-1308, 1981. 
5. Ramoser H., Laurain V., Bischof H., Ecker R., "Leukocyte Segmentation And Classification In Blood-Smear Images", 27th Annual International Conference of the Engineering in Medicine and Biology Society, 3371-3374, 2005.

6. Jiang K., Liao Q.-M., Dai S.Y., "A Novel White Blood Cell Segmentation Scheme Using ScaleSpace Filtering And Watershed Clustering", Proc. Intern. Conf. on Machine Learning and Cybernetics, Cilt 5, 2820-2825, 2003.

7. Ningning G., Zeng L., Wu Q. "A Method Based On Multispectral Imaging Technique For White Blood Cell Segmentation", Computers in Biology and Medicine, Cilt 37, 70-76, 2006.

8. Lezoray O., Cardot H., "Cooperation of Color Pixel Classification Schemes and Color Watershed: A Study For Microscopic Images", IEEE Transaction on Image Processing, Cilt 11, No 7, 783-789, 2002.

9. D'Elia C., Poggi G., Scarpa G., “A TreeStructured Markov Random Field Model for Bayesian Image Segmentation", IEEE Transactions On Image Processing, Cilt 12, No 10, 1259-1273, 2003.

10. Ruberto C., Dempster A., Khan S., Jarra B., "Analysis Of Blood Cell Images Using Morphological Operators," Image and Vision Computing., Cilt 20, No 2, 133- 146, 2002.

11. Liano,Q., Deng Y., "An Accurate Segmentation Method for White Blood Cell Images", Biomedical Imaging, 245-248, 2002.

12. Scotti F.," Automatic Morphological Analysis for Acute Leukemia Identification in Peripheral Blood Microscope Images", IEEE International Conference on Computational Intelligence for Measurement Systems and Applications, 2022, 2005 .

13. Bergen T.,Steckhan D., Wittenberg T., "Segmentation of Leukocytes And Erythrocytes In Blood Smear Images", 30th Annual International IEEE EMBS Conference, 30753078, 2008.
14. Yang-Mao S., Chan Y., Chu Y., "Edge Enhancement Nucleus and Cytoplast Contour Detector of Cervical Smear Images", Systems, Manufacturing and Cybernetics, Part B: Cybernetics, IEEE Transactions, Cilt 38, No 2, 353-366, 2008.

15. Mayumi D., Sabino U., Costa L., Rizzatti E., Zago M., "A Texture Approach to Leukocyte Recognition", Real-Time Imaging, Cilt 10, No 4, 205-216, 2004.

16. Khashman A. "Blood Cell Identification Using Emotional Neural Networks", Journal of Information Science And Engineering, Cilt 25, No 6, 1737-1751, 2009

17. Kasım Ö., Kuzucuoğlu A.E," "Identification of Diseased Leukocytes Cells From Blood Smear", $21^{\text {st }}$ International Conference on Signal Processing Systems, 1-4, 2013.

18. Ko B.C., Gim J.W., Nam J. "Automatic White Blood Cell Segmentation Using Stepwise Merging Rules And Gradient Vector Flow Snake", Micron, Cilt 42, No 7, 695-705, 2011

19. Utah University Hematopathology Index, "http://library.med.utah.edu/WebPath/HEMEHT ML/HEMEIDX.html”, (E.T.:29.01.2014)

20. Specht D.F., "Probabilistic Neural Networks", Neural Networks, Cilt 3, No 1, 109 -118, 1990

21. Otsu N., "A Threshold Selection Method from Gray-Level Histogram", IEEE Transaction on Systems, Manufacturing and Cybernetic, Cilt 9, No 1, 62-66, 1977.

22. Ravindraiah R. "Qualitative Evaluation of Enhancement Methods For Analysis Of Acute Leukemia Images", International Journal on Intelligent Electronic Systems, Cilt 5, No 2, 6447-6452, 2011.

23. Rezatofighia S., Zadeh H. "Automatic Recognition of Five Types of White Blood Cells in Peripheral Blood", Computerized Medical Imaging and Graphics, Cilt 35, No 4, 333-343, 2011. 
